\title{
Geologic Considerations in Underground Coal Mining System Design
}

Frank A. Camilli

David P. Maynard

Arnis Mangolds

Jack Harris

October 1, 1981

Prepared for

U.S. Department of Energy

Through an agreement with

National Aeronautics and Space Administration

by

Jet Propulsion Laboratory

California Institute of Technology

Pasadena, California. 


\section{DISCLAIMER}

This report was prepared as an account of work sponsored by an agency of the United States Government. Neither the United States Government nor any agency Thereof, nor any of their employees, makes any warranty, express or implied, or assumes any legal liability or responsibility for the accuracy, completeness, or usefulness of any information, apparatus, product, or process disclosed, or represents that its use would not infringe privately owned rights. Reference herein to any specific commercial product, process, or service by trade name, trademark, manufacturer, or otherwise does not necessarily constitute or imply its endorsement, recommendation, or favoring by the United States Government or any agency thereof. The views and opinions of authors expressed herein do not necessarily state or reflect those of the United States Government or any agency thereof. 


\section{DISCLAIMER}

Portions of this document may be illegible in electronic image products. Images are produced from the best available original document. 


\section{Geologic Considerations in Underground Coal Mining System Design}

Frank A. Camilli

David P. Maynard

Arnis Mangolds

Jack Harris

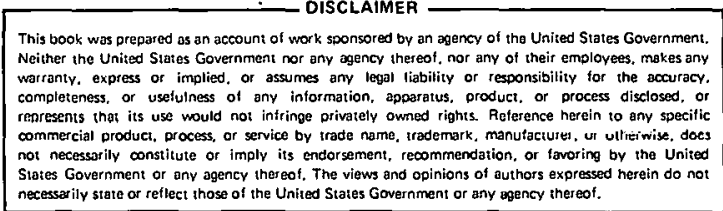

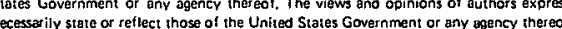

October 1,1981

Prepared for

U.S. Department of Energy

- Through an agreement with

National Aeronautics and Space Administration

by

Jet Propulsion Laboratory

California Institute of Technology

Pasadena, California 
Prepared by the Jet Propulsion Laboratory, California Institute of Technology, for the U.S. Department of Energy through an agreement with the National Aeronautics and Space Administration.

This report was prepared as an account of work sponsored by the United States Government. INether the Unlted States nur the Unted States Departiltellt of Energy, nor any of their employees, nor any of their contractors, subcontractors, or their employees, makes any warranty, express or implied, or assumes any legal liability or responsibility for the accuracy, completeness or usefulness of any

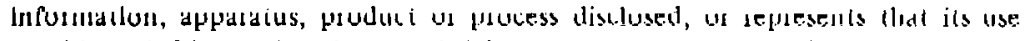
would not infringe privately owned rights. 
Geologic characteristics of coal resources which may impact new extraction technologies are identified and described to aid system designers and planners in their task of designing advanced coal extraction systems for the central Appalachian region. These geologic conditions are then organized into a matrix identified as the baseline mine concept. A sample region, eastern. Kentucky, is next analyzed, using both the. new baseline mine concept and traditional geologic investigative approach. The baseline mine concept presented is intended as a framework, providing a consistent basis for further analyses to be subsequently conducted in other geographic regions. The baseline mine concept is intended as a tool to give system designers a more realistic feel of the mine environment and will hopefully lead to acceptable alternatives for advanced coal extraction systems. 
FOREWORD

This document is one of a series which describe systems leve 1 requirements for advanced underground coal mining equipment. These requirements are summarized in "Overall Requirements for an Advanced Underground Coal Extraction System," JPL Publication 80-39, by Martin Goldsmith and Milton L. Lavin. Five areas of performance are discussed:

(1) Production cost.

(2) Miner safety.

(3) Miner health.

(4) Environmental impact.

(5) Recovery efficiency.

The report which follows discusses those aspects of coal geology which are relevant to the design of underground mining systems and then uses these ideas to develop a set of baseline mining conditions for the Central Appalachian resources. This work is part of an effort to define and develop innovative coal extraction systems suitable for the significant resources that will remain in the year 2000 .

ACKNÜWLEDGMENTS

The work presented here represents interim results from the Advanced Coal Extraction Systems Definition Project. This work is performed by the Jet Propulsion Laboratory, the California Institute of Technology, via interagency agreement No. DEA101-76ET12548, between the National Aeronautics and Space Administration (NASA) and the Office of Coal Mining, U.S. Department of Energy (DOE).

The authors would like to express their appreciation for the continuing support of the Project Officer, Mr. William Schmidt, Director of the Division of Coal Mining, U.S. Department of Energy, and the contributions made by C. $R$. Bickerton, M. Goldsmith, M. L. Lavin, A. Lynn, W. B. Mabe, and G. Varsi of JPL. 
CONTENTS

I. OBJECTIVES AND TECHNICAL APPROACH .................. . . 1-1

A. INTRODUCTION ........................ 1-1

B. REGIONAL FOCUS ....................... 1-1

C. DATA LIMITATION ON ANALYSIS . . . . . . . . . . . . 1-6

D. DOCUMENT OVERVIEW . . . . . . . . . . . . . . . . . 1-9

II. BASELINE MINE ENVIRONMENT FOR A TARGET RESOURCE . . . . . . . . . . 2-1

A. INTRODUCTION ...................... . . . .

B. GeOlogic Phenomena AFfecting mining . . . . . . . . . . . . 2-1

1. Overview ................... 2-1

2. Coal Deposition ................. 2-2

3. Roof and Floor Lithologies............. 2-4

4. Associated Features ............. 2-8

C. BASEline MINE . . . . . . . . . . . . . . . . 2-13

III. CHARACTERIZATION OF EASTERN KENTUCKY TARGET RESOURCE . . . . . . . 3-1

A. INTRODUCTION .................... . . . . .

B. TRADITIONAL GEOlOGIC INVESTIGATION ............ 3-1

1. Physiography .................. 3-1

2. Climate and Drainage ............. 3-3

3. Geologic Structure . . . . . . . . . . . 3-3

4. Sedimentation and Stratigraphy . . . . . . . . 3-6

5. Resource Estimate . . . . . . . . . . . 3-8

C. BASELINE MINE APPLIED TO EASTERN KENTUCKY . . . . . . . . . 3-10

D. COAL RESOURCE ANAlysis . . . . . . . . . . . . . 3-13

1. Nature of Topographic Slopes . . . . . . . . 3-13 
2. Dip of Coal Seams and Thickness . . . . . . . . 3-13

3. Relationship of Resource to Outcrop.........3-13

4. Resources Below Drainage ............ 3-15

5. Relationship of Resource to Interburden ...... 3-16

6. Overburden Thickness .............. 3-18

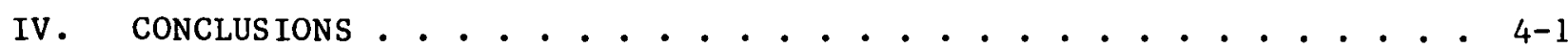

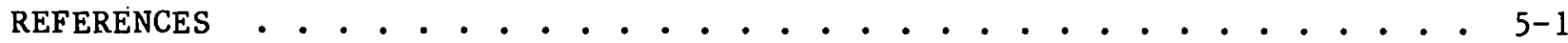

\section{Figures}

1-1. Major United States Coa1 Fields.............. . 1-2

1-2. Central Appalachian Coal Region .. . . . . . . . . 1-5

2-1. Depositional Environments of Eastern Kentucky Formations . . 2-3

2-2. Depositional Features Associated With Coal Deposits... . 2-10

3-1. Index Map of the Eastern Kentucky Coal Field Showing Physiographic Subdivisions, Uuadrangles, and Major Geographic Features ............... . 3-2

3-2. Structure-Contour Map of the Fire Clay Coal in Eastern Kentucky ................. . 3-5

3-3. Depositional Model for the Peat-Forming (Coal)

Environments in Coastal Regions .......... . . . 3-7

3-4. Coal Reserve Districts and Main Producing Areas

in Eastern Kentucky .. . . . . . . . . . . . . 3-y

3-5. Percentage of Eastern Kentucky Coal Resources Which are Separated from Adjacent Coal Seams by a Specified Interburden Distance ... . . . ......... 3-17

$\underline{\text { Tables }}$

1-1. Demonstrated Coal Resources by State . . . . . . . . . 1-3

1-2. Coal Production in 1977 . . . . . . . . . . . . 1-6

1-3. Eastern Kentucky Coal Résources . . . . . . . . . . . 1-6 
1-4. Demonstrated Coal Resources by Region .......... . . 1-7

1-5. Prediction Limits of Coal Reserves Based Upon Field Observations of Outcrops . . . . . . . . . . . . . 1-8

2-1. Depositional Environments . . . . . . . . . . . . 2-4

2-2. Roof Lithologies . . . . . . . . . . . . 2-6

2-3. Parameters of Baseline Mine . . . . . . . . . . . 2-14

3-1. Surface Water Discharge at Selected Eastern Kentucky

Stations... . . . . . . . . . . . . . . 3-4

3-2. Bituminous Coal Resources of Eastern Kentucky . . . . . . . 3-10

3-3. Baseline Mine for Eastern Kentucky (Seam thickness, depth, depth variations, subsidence, and access to be chosen by designer) ............. . . 3-14

3-4. Coal Seam Dip Relationship to Thickness in Eastern Kentucky ..................3-15

3-5. Coal Resources Related to Outcrop . . . . . . . . 3-16

3-6. Overburden Above Coal ................ . . . . . . . . . 


\section{SECTION I}

\section{OBJECTIVES AND TECHNICAL APPROACH}

\section{A. INTRODUCTION}

The Jet Propulsion Laboratory, under contract to the United States Department of Energy, is conducting a study to define, develop, and ultimately demonstrate advanced systems for underground coal mining. A requirement for advanced systems for use beyond the year 2000 is that they produce coal substantially below the production costs of existing systems. For the purpose of satisfying this requirement, the performance characteristics of an advanced mining system have been categorized into five primary areas: conservation, environmental protection, miner health, miner safety, and production cost. The evaluation of any advanced system must include an appraisal of the improvement anticipated in these five areas in order to determine its benefit to the existing mining industry. The Advanced Coal Extraction Systems Definition Project study is conducted on a basic premise that the specific geologic environment of a coal body will determine both the type and design of an advanced extraction system. Therefore, in order to support the conceptual development and design of such a system, this report identifies and describes those geologic characteristics of coal resources which may impact new extraction technologies.

As the target resources of this study are the coal deposits remaining in the United States in the year 2000 and beyond, the time span between the present and the year 2000 can be assumed sufficient to accommodate the incremental phases involved in creating and demonstrating an advanced extraction system. The study also assumes that a continuing national underground production of about one-third billion tons of coal a year between the present and the year 2000 will not significantly diminish the total known resources.

This study has undertaken no original resource investigation other than re-interpreting and categorizing previously published literature. A system requirements document has been generated which delineates the principal design criteria and establishes performance goals as well as general design. guidelines (Ref. 1). As background for these requirements, this report addresses the opportunities and limitations presented by the bituminous coal resources of the United States with respect to the circumstances under which they occur. A particular target region, eastern Kentucky, has been selected to illustrate the kinds of factors that define the operating environment for an advanced coal-extraction system.

\section{B. REGIONAL FOCUS}

The abundant coal resources of the United States are diverse in nature, dispersed in location, and only partly explored. These resources are illustrated on the map shown in Figure 1-1. Thirty-two states contain almost all of the national coal resources. Five states (Illinois, West Virginia, Montana, Pennsylvania and Wyoming) claim $73 \%$ of the total coal resources of the United States, as listed in Table $1-1$. 


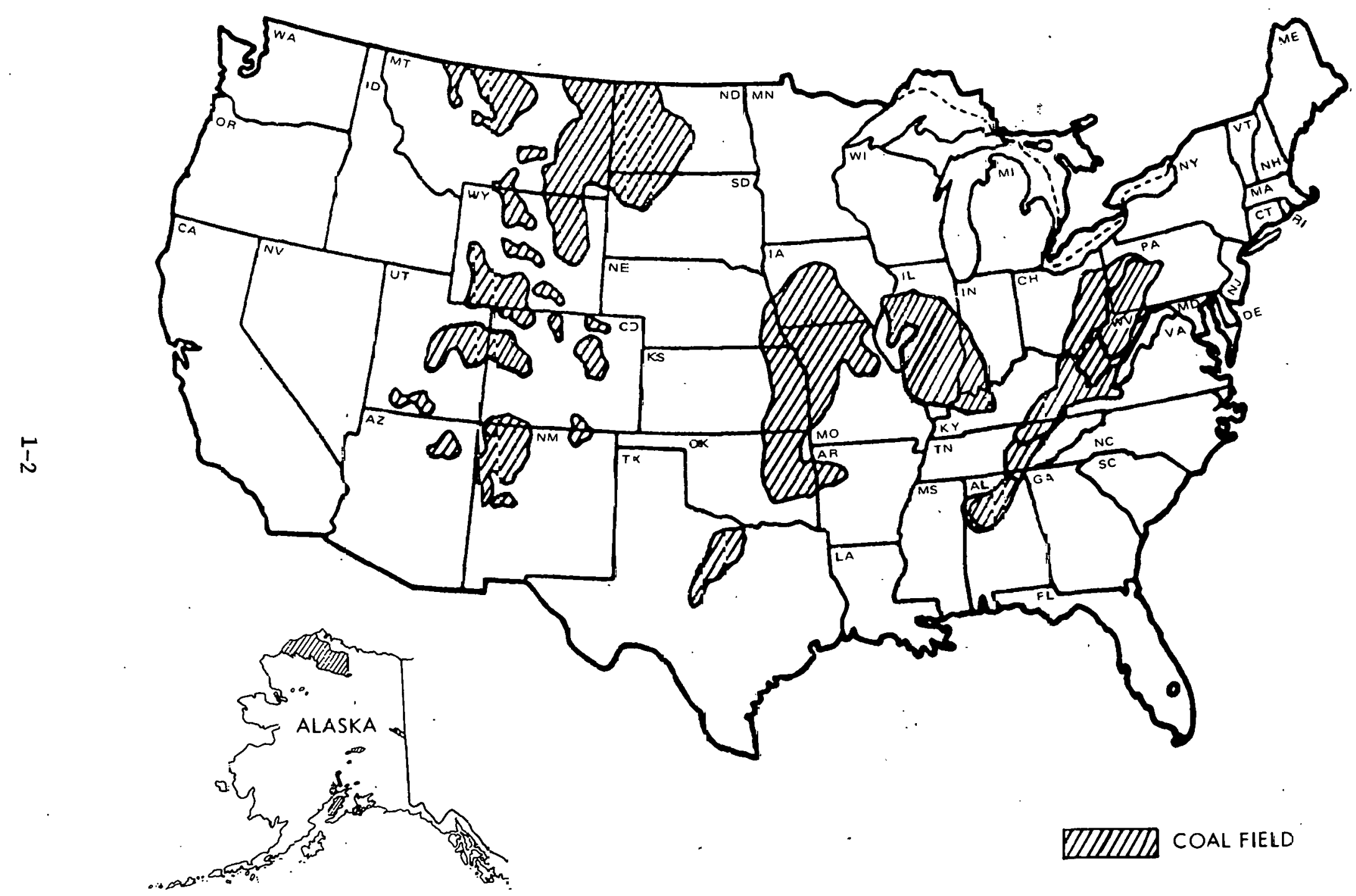

Figure 1-1. Major United States Coal Fields 
Table 1-1. Demonstrated Coal Resources by State, tons $\times 10^{6}$

\begin{tabular}{|c|c|c|c|c|c|}
\hline State & Anthracite & Bituminous & Subbituminous & Lignite & TOTAL $^{a b}$ \\
\hline Al ab ama & -- & $2,008.7$ & -- & $1,083.0$ & $3,091.7$ \\
\hline Alaska & -- & 697.5 & $5,446.6$ & 14.0 & $6,158.2$ \\
\hline Arizona & -- & 325.5 & -- & -- & 325.5 \\
\hline Arkansas & 96.4 & 270.1 & -- & 25.7 & . $\quad 392.2$ \\
\hline Colorado & 25.5 & $9,144.0$ & $4,121.3$ & $2,965.7$ & $16,256.4$ \\
\hline Georgia & -- & 0.9 & - & - & 0.9 \\
\hline Idaho & -- & 4.4 & -- & -- & 4.4 \\
\hline Illinois & -- & $67,969.3$ & -- & -- & $67,969.3$ \\
\hline Indiana & -- & $10,714.4$ & -- & -- & $10,714.4$ \\
\hline Iowa & -- & $2,202.2$ & -- & -- & $2,202.2$ \\
\hline Kansas & -- & 998.2 & -- & $-\dot{-}$ & 998.2 \\
\hline Kentucky, East & $\therefore-$ & $13,540.1$ & -- & -- & $13,540.1$ \\
\hline Kentucky, West & -- & $12,460.8$ & -- & -- & $12,460.8$ \\
\hline Louisiana & -- & -- & -- & c & $c$ \\
\hline Maryland. & -- & $1,048.3$ & -- & -- & $1,048.3$ \\
\hline Michigan & -- & 126.8 & -- & -- & 126.8 \\
\hline Missouri & -- & $5,014.0$ & $\quad--$ & $\cdot--$ & $5,014.0$ \\
\hline Montana & -- & $1,385.4$ & $103,416.7$ & $15,766.8$ & $120,568.9$ \\
\hline New Mexico & 2.3 & $1,859.9$ & $2,735.8$ & -- & $4,598.0$ \\
\hline North Carolina & -- & 31.7 & - & -- & 31.7 \\
\hline North Dakota & -- & -- & -- & $10,145.3$ & $10,145.3$ \\
\hline Ohio & -- & $19,230.2$ & -- & -- & $19,230.2$ \\
\hline Oklahoma & -- & $1,618.0$ & -- & -- & $1,618.0$ \\
\hline Oregon & -- & $c$ & 17.5 & -- & 17.5 \\
\hline Pennsylvania & $7,109.4$ & $23,727.7$ & -- & -- & $30,837.1$ \\
\hline South Dakota & - & -- & -- & 426.1 & 426.1 \\
\hline Tennessee & -- & 965.1 & -- & -- & 965.1 \\
\hline Texas & -- & -- & -- & $3,181.9$ & $3,181.9$ \\
\hline Utah & -- & $6,551.7$ & 1.1 & -- & $6,552.8$ \\
\hline Virginia & 137.5 & $4,165.5$ & -- & -- & $4,302.9$ \\
\hline Washington & - & 255.3 & $1,316.7$ & 8.1 & $1,580.1$ \\
\hline West Virgonia & -- & $38,606.5$ & - & -- & $38,606.5$ \\
\hline Wyoming & -- & $4,002.5$ & $51,369.4$ & -- & $55,371.9$ \\
\hline TOTAL & $7,371.1$ & $228,924.6$ & $168,425.0$ & $33,616.6$ & $438,337.3$ \\
\hline
\end{tabular}

ancludes measured and indicated resource categories as defined by the USBM and USGS and represents $100 \%$ of the coal in place.

bata may not add to total shown due to rounding.

${ }^{c}$ Quantity undetermined (basic resource data do not provide the detail required for delineation of reserve base).

SOURCE: USBM, "Demonstrated Coal Reserve Base of the United States in January, 1976." 
Bituminous and subbituminous coals occur in regions that are the modern geologic equivalents of marine and lacustrine basins where the coal origins once flourished and were subsequently buried by accumulating younger debris. Each coal basin contains formations that demonstrate regional characteristics and also reflect their own basinal structure, source areas, climate, etc. One such coal basin, Appalachia, extends nearly 900 miles, from northern Pennsylvania into middle Alabama. As shown in Figure 1-1, some of the other coal basins are diminutive and are located entirely within the borders of one state. It is as yet unclear how the regional differences among coal resources would affect the specification of requirements for an advanced underground coal mining system. Therefore, for the purpose of concept development, it was decided to choose one target region and create the system requirements for an advanced mining system in terms of that geographic area.

The criteria for selecting a target region were: (1) an area must be chosen whose resource would be of consequence in the time period of interest (the year 2000 and beyond); (2) a market must be expected to exist for coal from the area; and ( 3 ) the mining conditions should present a challenging technical eituation.

After careful consideration, central. Appalachia was chosen as the target region (Figure 1-2). This choice was based on several factors. First, a substantial fraction of U.S. coal is produced in central Appalachia, as shown in Table 1-2 (eastern Kentucky is shown as a subregion). Because most of the detailed analysis used in this report is based on eastern Kentucky data, this area was chosen as the data area. As an example, Table 1-3 shows the coal reserves of eastern Kentucky. The inference from the two tables is that central Appalachia represents a significant factor of U.S. coal production, and that the reserves in the data area (eastern Kentucky) will be ample to support mining for an extended time. In addition, the industrial activities of the East Coast are predicted to continue to provide a market for Appalachian coal.

A review of the mining situtation in central Appalachia revealed that a variety of geologic conditions exist. Seams are characterized by variable thickness, with differing roof and floor structures. Generally, the production cost of coal is higher than in some other areas, indicating that mining conditions may be more difficult. Thus, the focus on central Appalachia appears to meet the selection criteria.

After the initial selection of central Appalachia as the target region, the decision was made to further scale-down the target region, and the subregion of eastern Kentucky was chosen as a particularly suitable sample. Eastern Kentucky covers an area of 10,000 square miles and offers a thick series of Appalachian coal deposits. All of eastern Kentucky's coal is of the bituminous rank, most in the medium-volatile "A" class, and some in the upper low-volatile coking classification. The "eastern" field in Kentucky is geologically distinct from Kentucky's western coal regions, which are a part of the Eastern Division of the Illinois basin. There is barren zone between the two fields, the southern portion of the Cincinnati Arch presenting an inter-basinal relief. 


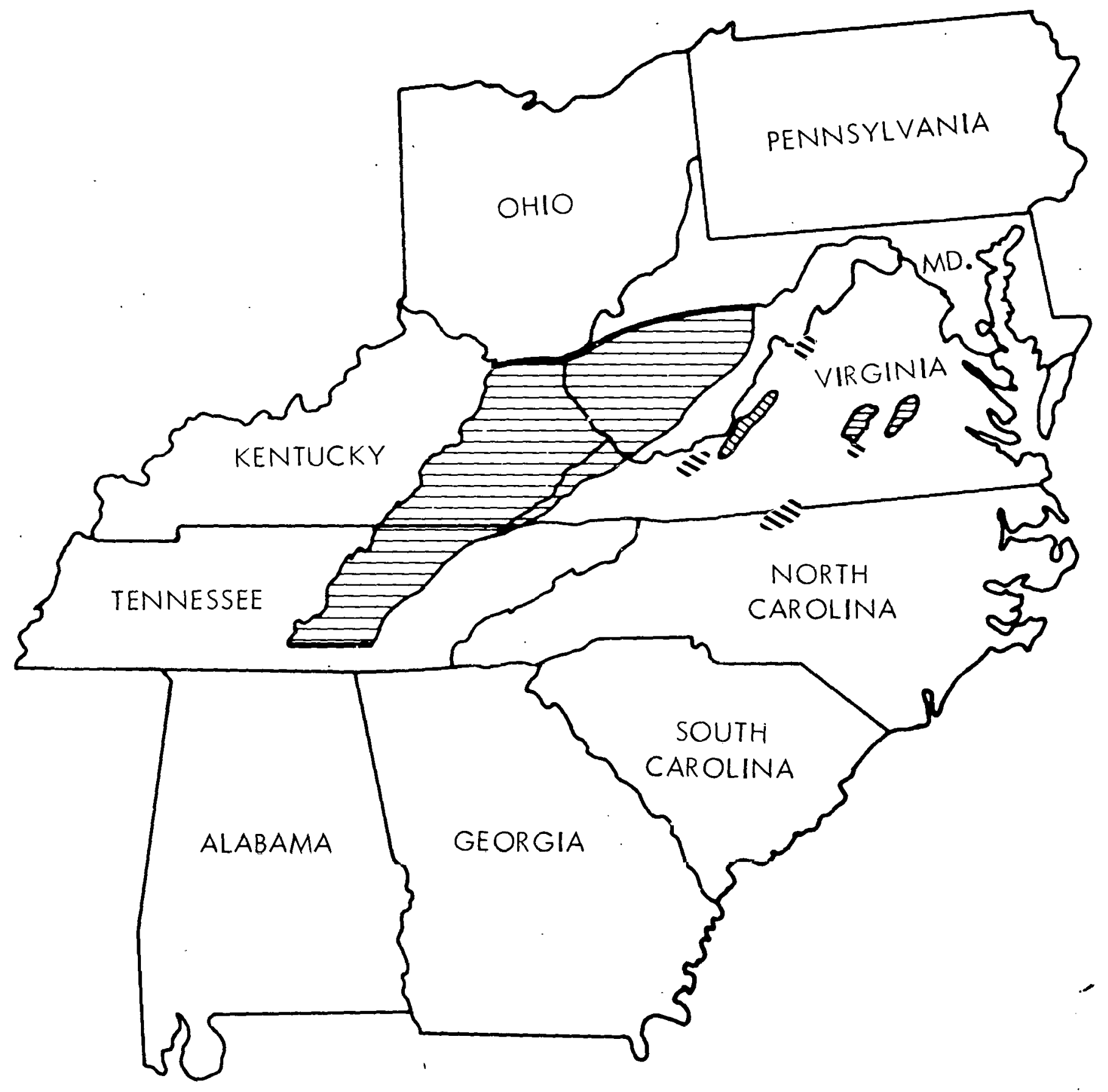

Figure 1-2. Central Appalachian Coal Region 
Table 1-2. Coal Production in 1977 , tons $\times 10^{6}$

Total U.S. Production

689

U.S. Underground Total

272

Central Appalachia Underground $\quad 146$

Eastern Kentucky Underground

41

Source: U.S. Bureau of Mines (1977).

Table 1-3. Eastern Kentucky Coal Resources, tons $\times 10^{6}$

$\begin{array}{ll}\text { Proven Resources } & \\ \text { In-HIace } \Lambda \text { bandoncd } & 3,100^{2} \\ \text { Thin Seams (28 inches) } & 9,100 \\ \text { Thick Seams } & 9,000 \\ \text { Shallow Coal } & 4,400 \\ \text { Inferred Resource } & 5,200 \\ \text { Hypothetical } & \underline{24,000}\end{array}$

Total Resources $\quad 54,900$

$a_{J P L}$ estimate.

Sources: USGS Bulletin 1412 (1975) and USGS Bulletin 1120 (1963).

C. DATA LIMITATION ON ANALYSIS

Data describing any of the regional coal resources are a collection of generalizations. Coal basins are typically explored, mapped and reported as resources separately by the states, resulting in only partial correlation across state boundaries. Consequently, regional resources, and even the compilation of national coal resources, are the statistical composites of state claims. However, the national agencies, especially the United States Geological Survey (USGS) and the United States Bureau of Mines (USBM), have. influenced these accountings, and their Federal mandate makes possible regional, as well as the national, resource statements. Table 1-4 presents a regional tabulation of coal resources.

Even though the coal resources of eastern Kentucky are well identified, mapped and documented, the data are not sufficient for systems engineering and 
Table 1-4. Demonstrated Coal Resources By Region, tons x $10^{6}$

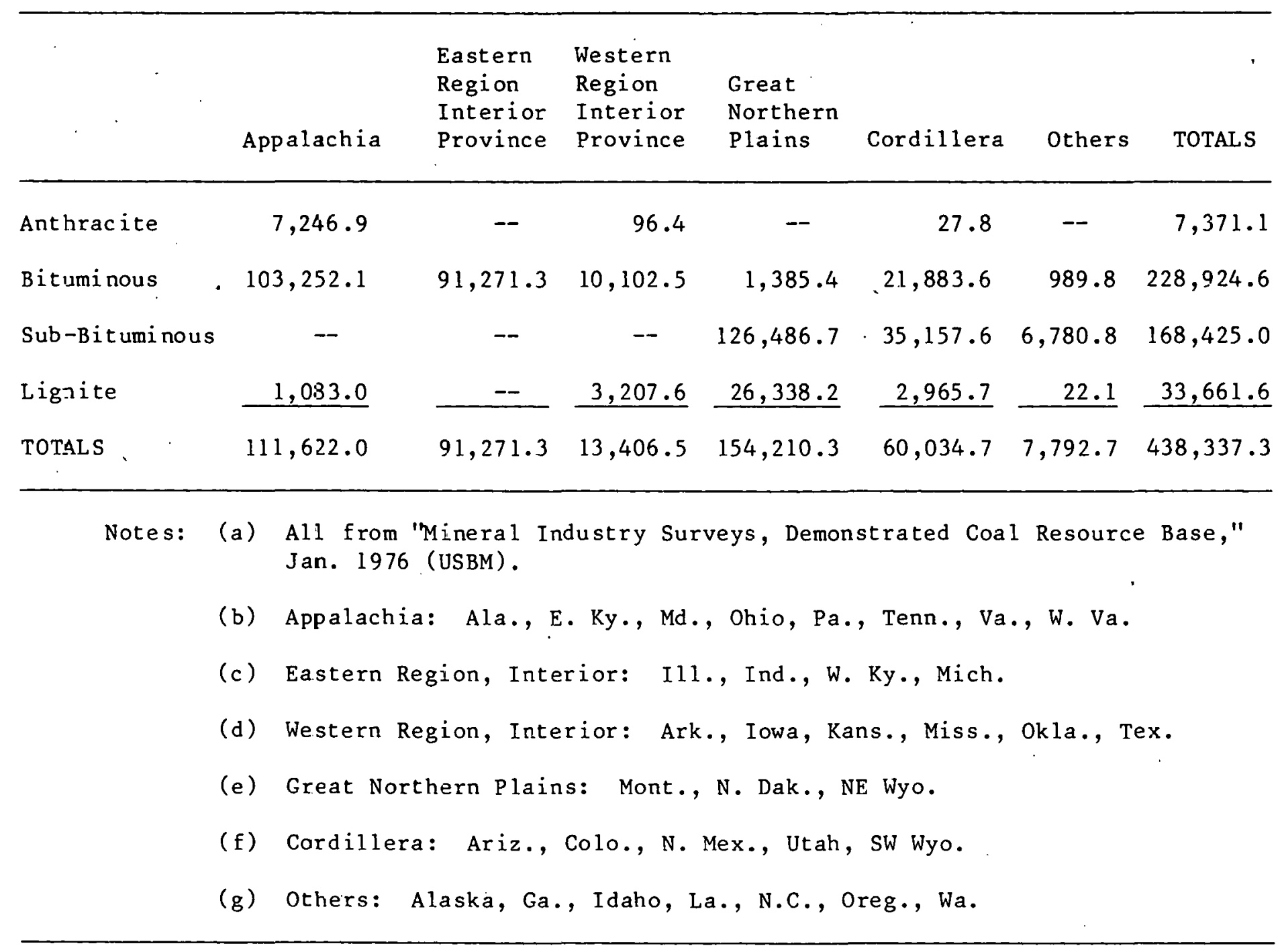


design purposes. Few of the details that a mine designer or operations planner would need to plan a new venture are available from the published material. The literature provides an adequate tabulation of the quantity of coal in a given region, but it furnishes only a generalized description of the geologic features of the area. Coal bodies of an extremely variable thickness have been described as "varying from 0-inches to 72-inches thick." Some descriptions of roof rock, determined by assessments made at scattered outcrop points, suffer from the same type of generalized characterization, when in actuality their quality may vary from shale to siltstone to sandstone. Interburden thicknesses between coal seams vary dramatically in eastern Kentucky and are also treated in an extremely generalized manner. Data describing the amounts and locations of methane and ground water in eastern Kentucky are not available.

The practice of mapping geologic features on established topographic surveys requires the mapper to reveal the presence of geologic characteristics concealed by soil creep, weathered exposures and slump. At times, the geologist must interpret the continuity of the outcrop and its thickness. Weighted values have been assigned to field observations, and Table 1-5 1ists the established limits for assuming the continuation of a coal seam observed in a distinct, fresh outcrop. These practices have been generally accepted, but they fall short of the detail sought for statistical analys is and for systems engineering.

Eastern Kentucky has been mapped by the combined forces of the Kentucky Geological Survey (KGS) and the USGS. A quantity of 220 seven-and-one-half minute quadrangle maps describe the area, with surface geology detailed on topography at a scale of 1:24,000. A total of 187 of these quadrangle sheets are now available for public use, and were utilized in the study.

Resource estimates accounting for each coal member in each quadrangle have not yet been prepared. The authors utilized the statistics developed by Huddle, et al, as given in USGS Bulletin 1120 (1963), which is still considered the best reference. Huddle developed the resource data for six reserve districts in eastern Kentucky and sought to establish premining assessments by coal seam; consequently, any contemporary use of that data must make allowance for mining depletions.

In the study and evaluation of the sample region's resources, the Federal agencies have relied upon substantial data from mining industry operations and from oil and gas explorations. Such information, coming from drilled-hole logs and samples, from measurements in underground openings, and from surface excavations, supplements measurements obtained by surface mapping,

Table 1-5. Prediction Limits of Coal Reserves Based Upon Field Observations of Outcrops

Coal Reserve, Category

Measured Reserves Indicated Reserves Inferred Reserves
Maximum Seam Extension, miles

0.5

1.5

2.0 
and contributes to the conclusions presented on the quadrangle maps. However, the study reported here has not had the advantage of such detailed information, nor has it sought data other than those generalizations developed from. the quadrangle maps.

\section{DOCUMENT OVERVIEW}

Despite the wide range of science and engineering possibilities for the design of an advanced coal extraction system, the application of any such system must accomodate the target coal resources. This study seeks to describe a methodology that can be used to quantify and characterize the coal resources of a sample locality and to apply this methodology to the coal resources of eastern Kentucky. A further intent of this study has been to determine and present; (1) key resource measurements, (2) an explanation of the resource origins and the influence of those origins upon present geologic conditions, and ( 3 ) a classification of the coal resource characteristics of the sample region.

Section II describes the general geologic conditions of which a typical mine environment is composed. These geologic conditions have then been organized by varying degrees of severity into a matrix identified as the baseline mine concept. By using this matrix, the designer can configure the baseline mine to match the level of sophistication of the conceptual advanced mining system.

In Section III, the specific target resources of eastern Kentucky are addressed from three points of view. The first approach is the traditional geologic investigation. Summaries of the physiography, climate and drainage, structure, sedimentation and resource estimate are presented. Secondly, the baseline mine concept developed in Section II is applied. Finally, the findings of various analyses relating the significance of specific geologic parameters to the coal resource of eastern Kentucky are presented.

Section IV concludes the report with a brief summary and some thoughts regarding further extensions of this effort. 


\section{SECTION II}

\section{BASELINE MINE ENVIRONMENT FOR A TARGET RESOURCE}

\section{A. INTRODUCTION}

A review of current mining technology reveals that most components/ systems utilized in underground coal mines are designed to operate under a relatively narrow range of geologic conditions. Mine layouts, roof supports, production machinery, ventilation systems, etc., must be tailored to the particular environment and dimensions associated with the target seam.

An extremely worthwhile goal is the design of mining systems that can be used in widely differing environments. However, this objective poses several problems in evaluation. To tabulate all of the variables imposed on such a system and to ask the designer to create a system which can operate effectively under all circumstances will be an overwhelming task, and one which certainly will be difficult to achieve. . On the other hand, evaluating a system against a single model - either artificial or real - can result in a system that is too restrictive in terms of general applicability. Furthermore, failure to consider a parameter of seemingly secondary importance for one application may result in a serious oversight for another application.

It is believed that the evaluation methodology presented here circumvents the previously mentioned difficulties by allowing the designer to create his own model working environment - the baseline mine. However, before the baseline mine can be developed, the physical phenomena most commonly affecting mine operations must be examined.

\section{B. GeOlogic Phenomena AFFECting Mining}

\section{Overview}

Every aspect of mining is intimately related to the geologic environment associated with the coal body it intends to exploit. Most mining systems have dimensional limitations, either in terms of maximum horizontal reach or minimum operating height. If a mining system is dependent upon a particular coal geometry or a specific mining sequence for successful operation, the continuity and consistency of the coal seam and its attendant components (roof, floor) become critical. Engineering parameters such as material strengths and behaviors are also generally a direct result of the lithology and geologic history of a given coal bed. Although the value and geographic distribution of many of the factors appear to be random, the informed geologist, with sufficient data and an understanding of the formative processes, may identify a number of predictable trends. Trend identification frequently requires considerable detective work. Such esoteric details as whether the transition of the grain size within the sandstone was uniform or random (i.e., graded or mottled), or whether the shale contained burrows or roots are of little use to the layman but are of vital importance in 
reconstructing the original depositional environment. Once the stratigraphic and tectonic style of a region has been characterized, the mining geologist can then translate these results into terms of engineering significance. Vital aspects such as partings, splits, sandstone cahnnels and areas of good or bad roof can be predicted to some degree. Finally, the geotechnical engineer will transform the above information into design parameters.

The design of every mine should take into consideration the contingency of encountering a possible "worst case" disaster. Because of the variability encountered in coal geology and because even the most detailed investigations will probably miss some anomalous zones, it is important that a mine design should allow for flexibility. For example, if poor roof conditions are unexpectedly encountered, a collapse could compromise or even threaten the survival of a mining system that is intended to develop isolated, unsupported panels. Similarly, unexpected faults, pinchouts, splits, etc., can play havoc with even the more traditional systems.

\section{Goal Depoeition}

Coal is a product of thick vegetal accumulations most commonly associated with the peats found in swamp and marshlike environments. Louking at today's wetland ecologies, it can be seen that very distinct classes of wetland environments exist. For example, the marsh of the Mississippi Delta differs widely in process, sediment, vegetal content, and physical distribution from the Florida Everglade swamps or the barrier island marshes of New Jersey. However, each of the previously mentioned environments is capable of producing peat in sufficient quantity to form coal. It follows, therefore, that individual coal seams and the associated strata will reflect their original depositional setting; that is, an everglade-type environment will form broad, evenly distributed coal beds such as those found in the Illinois coal basin, while on the other hand the deltaic (near-shore) coal commonly found in central Appalachia will be more fragmented in both distribution and quantity. Furthermore, the deltaic environment will produce a coal seam with a greater variety of associated strata than a seam formed in an everglade environment. It has been found that the various depositional settings can be classified into subenvironments, each with its own recognizable features. Horne, et al, (1979) have categorized each of the subenvironments common to Appalachia, and described their distinguishing features.

Figure 2-1 illustrates and Table 2-1 summarizes the various depositional environments. Although the performance of a depositional analysis requires a great deal. of insight and background data, a knowledge of the depositional environment can provide a number of clues regarding possible ground-control problems for a given coal field. Local soil structure, topograpliy and drainage dictate the vegetal growth densities and therefore the thickness of the peat. Relative rates of vegetal growth, erosion, and sedimentation affects the spatial distribution of partings, splits, roof and floor types, etc. For example, in eastern Kentucky, the southern half of the coal field experienced pronounced subsidence, as evidenced by the thickening of the time-rock sequence. As a result, the peat-forming environments could not develop and consequently the coals south of the hinge line (Paint Creek-Irvine 


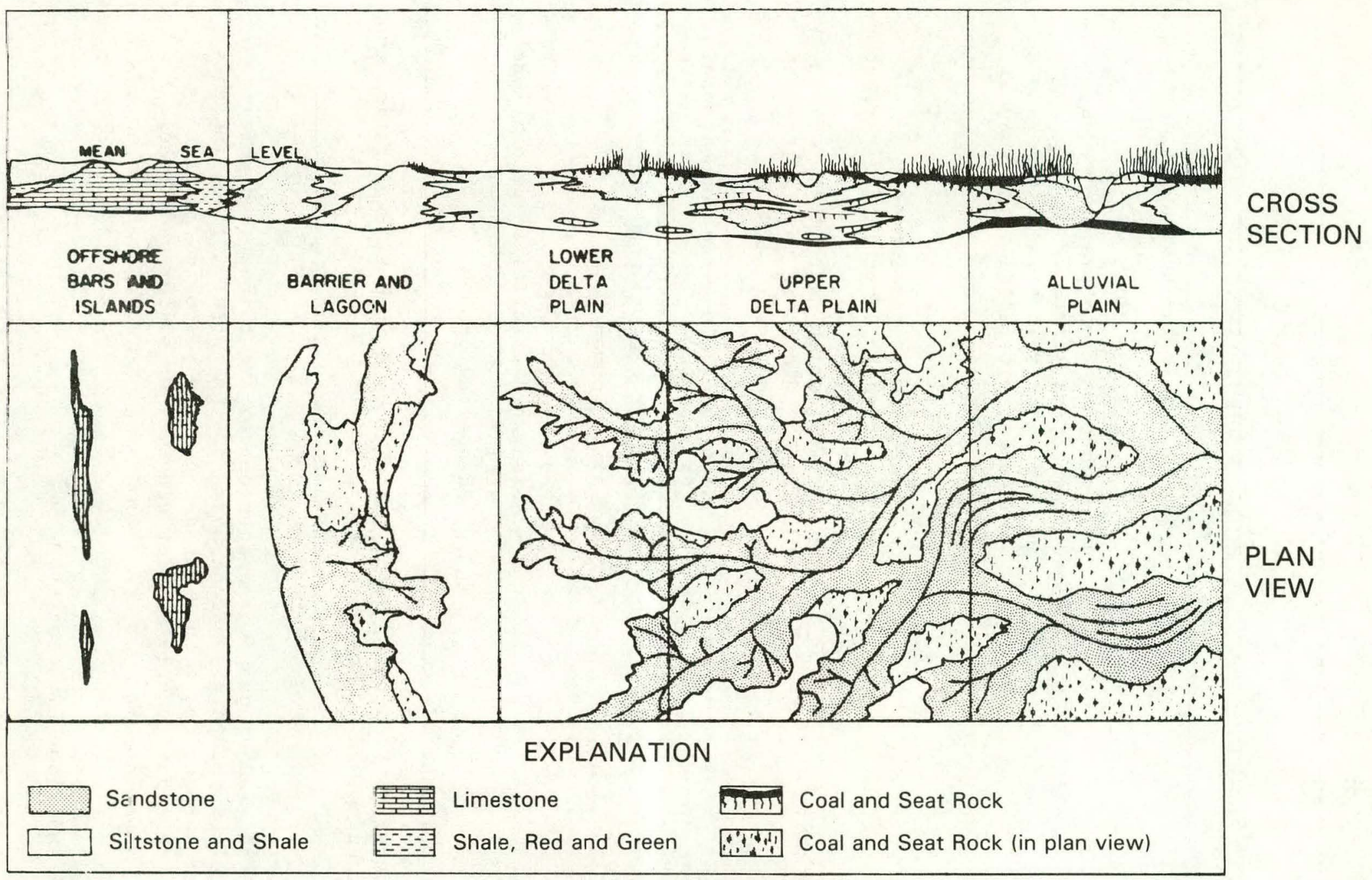

Source: Ferm, J.C. and Horne, J.C. (1979).

Figure 2-1. Depositional Environments of Eastern Kentucky Formations 
Table 2-1. Depositional Environments

Alluvia1 plain

Upper De1ta Plain

Lower Delta Plain

Barrier

Source: South Carolina Preprint, "Depositional Models in Coal Exploration and Mine Planning," J.C. Horne, et al.
- Less continuous than upper delta plain

- Pod-shaped

- Occurs in flood plains between wandering streams

- Rapid variations in thickness

- Elongated parallel to the deposition dip

- Most important resource

- Extensive in large interdistributary bays

- Splits common near levees

- Roughly elongated parallel to the depositional strike

- Continuous along the depositional dip direction

- Discontinuous along the depositional slrike

Splits common

- Pod-shaped

- Elongated parallel to depositional strike

- Channeling common

fault zone), in the area of pronounced subsidence, are thinner and more 1 imited in lateral extent than the coal seams to the north. offsetting this dimensional disadvantage, coals forming in the rapidly subsiding areas generally contain a significantly smaller quantity of sulfur and trace elements.

3. Roof and Floor Lithologies

All of the strata immediately associated with coal in central Appalachia are sedimentary in origin even though this is not necessarily the case in other coal basins. Both the composition and distribution of the roof and floor are therefore subject to the same depositional constraints as coal. 
The predominant roof types are shale, siltstone, sandstone, channel coal, limestone and clay. It is possible that all grades or combinations of these lithologies may occur, and they are likely to be encountered somewhere within a given coal basin. Floor lithologies are most commonly fireclay and shale, although siltstones, carbonaceous shales and sandstones do occur. Table 2-2 (modified from Horne, et al, 1978) summarizes the types of roof lithology, their various depositonal environments, and some of the inherent problems associated with each type.

a. Roof. Inspecting Table 2-2, it appears that the coarser-grained lithologies result in a roof that is less likely to fail than those composed of fine-grained lithologies. Furthermore, the presence of coarse-grained lithologies implies that deposition occurred within a relatively high-energy environment such as the fluvial, onshore, or barrier-island type. Unfortunately, high-energy depositional environments imply the presence of complimentary erosional forces. In fact, it can be seen from Table 2-2 that the occurrences of coal associated with high-energy depositional environments are spotty or relatively discontinuous.

Peat bogs occurred naturally within the active biosphere, and alterations to the rock structure resulting from the previous plant and animal life frequently affect structural behavior. Worm burrowings homogenize the rock mass, destroying interlocking mineral fabric. Plant roots decay and fill with clays of little shear strength. Roof rock, dissected by dense root structures or dessication cracks, is very weak and often must be avoided. Petrified tree stumps (kettles) also exhibit very low shear strengths along their sides as a result of differential compaction along the clay interface and may drop out of the roof without warning. Differential compaction can result from the fact that, under a 2,000- to 4,000-foot overburden load, sands compact 10 to $15 \%$ of their volume while shales experience a 15 to $50 \%$ volumetric compaction. Differential compaction of horizontally adjacent lithologies often create slickensides along the shear face that have little or no bond strength. Slickensides may also be found along sandstone channels, clay veins and concretions. Mining systems which hope to sustain unsupported openings in these types of rock have little chance of success, whereas greywacke, sandstone, and some shale roofs can remain stable over wide spans for long periods of time.

In addition to the previously mentioned kettles, concretions may also abound in the roof. Concretions are semispherical nodules of claystone (shale), pyrite, siderite, or calcite that range from microscopic in size to a diameter of several feet. Concretions result from the chemical precipitation which typically forms around a nucleus such as a fossil. Differential compaction around the nodules form slick surfaces that have little adhesion to the surrounding rock, thereby allowing concretions to fall out of the roof. In some shale roofs, concretion populations may be quite dense and generate severe roof problems.

b. Floor. The strata underlying a coal seam act as the foundation material which supports all overlying strata, artificial supports, and the mining machinery. Although the floor material of a particular coal seam is usually fairly consistent within the area of a mine property, the floor 
Table 2-2. Roof Lithologies

\begin{tabular}{|c|c|c|c|}
\hline Roof Stability & Lithology & Conditions and Remarks & Depositional Environment \\
\hline Excellent & Gre ywacke & $\begin{array}{l}\text { Lag deposizs; shale, coal } \\
\text { pebbles ian weaken base of } \\
\text { strata }\end{array}$ & $\begin{array}{l}\text { Result of active, laterally } \\
\text { migrating streams } \\
\text { Upper delta plain-fluvial } \\
\text { Transitional delta plain }\end{array}$ \\
\hline Good-excellent & Orthoquartzitic & $\begin{array}{l}\text { Often closıly jointed; can } \\
\text { cause severe roof falls }\end{array}$ & $\begin{array}{l}\text { Back barrier } \\
\text { Barrier }\end{array}$ \\
\hline Poor-good & $\begin{array}{l}\text { Flat-bedded Sandstone, } \\
\text { interbedded Sandstone }\end{array}$ & $\begin{array}{l}\text { Stability lepends on thickness } \\
\text { Thicknesses less than } 2 \text { ft can } \\
\text { exhibit separation along } \\
\text { bedding planes } \\
\text { Thick beds develop slickensides } \\
\text { due to differential compaction } \\
\text { (greater than } 10 \mathrm{ft} \text { ) } \\
\text { 2-ft - 10-ft thick beds best } \\
\text { structurally }\end{array}$ & $\begin{array}{l}\text { Found along flanks of } \\
\text { distributary mouth bars } \\
\text { Lower delta plain } \\
\text { Transitional lower delta plain }\end{array}$ \\
\hline Poor-good & $\begin{array}{l}\text { Coarsening upward } \\
\text { shale, shale with } \\
\text { sandstone, sandstone } \\
\text { with shale, sandstone }\end{array}$ & $\begin{array}{l}\text { Separates at sandstone/sinale } \\
\text { bedding }\end{array}$ & $\begin{array}{l}\text { Bayfill } \\
\text { Lower delta }\end{array}$ \\
\hline Very poor & $\begin{array}{l}\text { Seat earths, draw } \\
\text { slates, (silty clays, } \\
\text { roof-penetrated) }\end{array}$ & $\begin{array}{l}\text { Little strength, poor anchorage, } \\
\text { must remove or leave coal } \\
\text { Roots, slickenside } \\
\text { Fine-grained }\end{array}$ & $\begin{array}{l}\text { Upper delta plain-fluvial } \\
\text { Transitional lower delta } \\
\text { plain }\end{array}$ \\
\hline Poor-very poor & $\begin{array}{l}\text { Cube rock } \\
\text { (carbonaceous black } \\
\text { shale, highly jointed) }\end{array}$ & $\begin{array}{l}\text { Always requires bolting } \\
\text { Brittle, ronbedded, highly } \\
\text { jointed }\end{array}$ & $\begin{array}{l}\text { Occurs during drowning in low- } \\
\text { energy reworking environment, } \\
\text { common to all settings } \\
\text { Most frequent ly in lower } \\
\text { transitional lower delta, } \\
\text { lower delta plain }\end{array}$ \\
\hline
\end{tabular}


Table 2-2. (Cont'd)

\begin{tabular}{|c|c|c|c|}
\hline Roof Stability & Lithology & Conditions and Remarks & Depositional Environment \\
\hline Poor-very poor & $\begin{array}{l}\text { Burrowed siltstone, } \\
\text { shale, shale } \\
\text { with sandstone }\end{array}$ & $\begin{array}{l}\text { Must bolt } \\
\text { If burrowing extensive, may } \\
\text { require removing or leaving } \\
\text { coal }\end{array}$ & $\begin{array}{l}\text { Areas of slow sedimentation } \\
\text { Marine, brackish, back barrier } \\
\text { lower delta plain, } \\
\text { transitional lower delta } \\
\text { plain }\end{array}$ \\
\hline Very poor & $\begin{array}{l}\text { Kettles } \\
\quad \text { (petrified tree } \\
\text { stumps) }\end{array}$ & $\begin{array}{l}\text { Requires removal or bolting } \\
\text { Tree ccre filled with sedi- } \\
\text { ment, outer skin coalifiers; } \\
\text { poor strength, geometrically } \\
\text { unstable } \\
\text { Several hundred pounds }\end{array}$ & $\begin{array}{l}\text { Common to all areas } \\
\text { Frequent in upper delta plain, } \\
\text { fluvial transitional lower } \\
\text { delta plain }\end{array}$ \\
\hline Poor & $\begin{array}{l}\text { Slickensides along } \\
\text { sandstone-shale } \\
\text { interfaces }\end{array}$ & $\begin{array}{l}\text { Must bolt } \\
\text { Slickenside developed due } \\
\text { to differential compaction }\end{array}$ & $\begin{array}{l}\text { Lower delta plain } \\
\text { Back barrier }\end{array}$ \\
\hline Very poor & $\begin{array}{l}\text { Channel-bank slump } \\
\text { blocks }\end{array}$ & $\begin{array}{l}\text { Should be avoided, bolting, } \\
\text { bracing ineffective } \\
\text { Ancient landslide (slump) } \\
\text { surfaces }\end{array}$ & $\begin{array}{l}\text { Along cutbank side, laterally } \\
\text { migrating, meandering stream } \\
\text { channels } \\
\text { Upper delta-fluvial } \\
\text { Transitional lower delta plain } \\
\text { Back barrier }\end{array}$ \\
\hline Poor-very poor & Rider coals & $\begin{array}{l}\text { If rider seam is within } 20 \mathrm{ft} \\
\text { of main seam, will fail up } \\
\text { to upper seam } \\
\text { Avoid or mine on retreat } \\
\text { Roof usually heavily rooted } \\
\text { Frequent partings }\end{array}$ & $\begin{array}{l}\text { Crevassed levees, splay } \\
\text { deposits } \\
\text { All delta plain } \\
\text { environments }\end{array}$ \\
\hline
\end{tabular}

Source: South Carolina Preprint, "Depositional Models in Coal Exploration and Mine Planning," J.C. Horne, et al. 
properties may vary greatly over the entire region of a seam. The floor materials of central Appalachia range from soft, plastic clays (also called underclays, fireclays, seat earth, etc.), shales and siltstones to an occasional hard sandstone or shale. Underclays cause the most troublesome conditions and they may form the immediate floor or they may be overlain by shales and siltstones. Most of the floors typically contain large percentages of clay minerals (kaolin and illite) which deteriorate when exposed to water.

The structure of the floor is essentially the same as the roof. The floor materials and geometry are a function of the depositional environment prior to formation of the peat bogs. In central Appalachia, this environment was essentially deltaic, nearshore and barrier is land. Floor lithologies can vary in thickness from several inches to tens of feet.

The wide range of floor materials causes complicated behavioral responses to in-mine stresses. While the soft clays follow the principles of soil mechanics, the stiff shales and sandstones behave according to very different rock mechanics formulae. Large percentages of clays present in siltstones and shales result in both sojl-like and rock-1ike rharacteristirs heing presont in floors.

\section{Associated Features}

Although the quality of the roof and the floor as well as the coal itself generally dictates the mining system used, many secondary geologic features can have a major effect on roof stability and/or cutting efficiency: Therefore, the occurrence and character of such features, i.e., partings, sandstone channels, clay veins, sedimentary structures, and mechanical discontinuities are presented in the following text.

a. Partings. Partings are layers of clay, ehale, oiltotonc, or sandstone that hor izontally intersect a coal seam. Their position relative to the coal seam may vary from the roof to the floor, and they may be paper thin to several feet in thickness. Floods or high tides which carried heavy sediment loads over the peat bogs are one of the mechanisms by which partings may have been formed. Flood-originated partings are obviously thickest near the river banks, berms, or levees, and become thinner as they project outward. The coarsest-grained sediments also lie nearest the sediment source. These flood deposits, called crevasse-splays, have been known to range from 5- to 500-meters wide and 200- to 1000-meters long. Parting lithology reflects the energy balance present during formation, from the sandstones of turbulent streams or tidal channels to the lower-energy sandy siltstones, to siltstones, to shales.

b. Sandstone Channels. The presence of sandstione channels on a mine property can have severe consequences on the dollar value of the property and the effectiveness of a mining system. Sandstone channels are the infilled remnants of old stream or river beds which dissected the peat zones contemporaneously or eroded them away after deposition. Sandstone channels may range from several miles in width and several hundred miles in length (Walsville Channe 1 in the Illinois basin, on the Herrin 非 seam) to the size 
of a small stream bed. The channel may completely obliterate the coal seam or may only partially intersect it. Ancient river beds had the same random appearance as those of today, containing meanders, tributaries, islands, oxbows, etc. In such cases, exploration is difficult and is further complicated when coal pockets are bracketed by sandstone channels. Aside from the obvious loss of coal, sandstone channels are associated with numerous roof problems. The Mine Safety and Health Administration (MSHA) has compiled a list of key characteristics associated with channels, some of which may act as clues for the early detection of a sandstone channel (MSHA IR 1096).

Figure 2-2 illustrates the general shape of a typical sandstone channel. Channel fill is most commonly greywacke, although siltstones, shales, or sandstones may also provide fill. The lag deposits or coarse-grained material at the trough (apex) varies widely in strength but is generally difficult to cut regardless of the composition. As the channel is approached, partings appear, or if they are already present, they increase in thickness. The coal may actually split into benches. Coal elevations may change as the peat climbs the river levees. Bed thickness of the coal seam may increase in the proximity of a sandstone channel, and the coal chemistry also tends to exhibit some variation. Secondary pigmentation from the more porous sandstone increases the sulfur content. The content of ash, phosphorous, trace elements, and moisture in the coal can also vary due to the different micro-ecological environment on a river bank for contemporaneouslyformed channels. Water seepage through roof joints and boreholes may occur several hundred feet out by actual intersection and the resultant clay swell in roof bolt holes could weaken anchor points. Bedding planes in claystones and shales could disappear as a result of flow assoicated with differential compaction. Occurrences of slickensides and joints also increase as the channel is approached, again due to differential compaction. Technically, the change in thickness and elevation of the coal bed immediately adjacent to the eroded or nondepositional "want" area is termed a roll. This roll formation is not similar to tectonic folds, pinches, or areas where the predepositional topography was rolling.

c. Clay Veins. Clay veins or dikes are masses of clay or shale which have been injected from the roof, or occasionally the floor, into the coal bed. Clay veins range from a few inches to several feet in thickness, and may extend laterally several hundred feet. Clay veills art usually associated with fold axes, and tend to exhibit a parallelism with the predominant cleat directions. Their inverted, conical structure (also called a horseback) exhibits little cohesion and easily falls out, creating a dome-shaped cavity. The impermeable nature of clay veins can cause accumulation of methane.

d. Sedimentary Structures. Primary sedimentary structures are features that are contemporaneous with initial depositional, erosional, and diagenetic phases. They result primarily from variations in current velocities, sedimentation rates and composition. Differences in cohesion due to grain type and size variations may create mechanically weak zones along the interface of the sedimentary structure. Examples of this predicament are bedding planes, dessication cracks, ripple marks, crossbedding, 1ithologic 


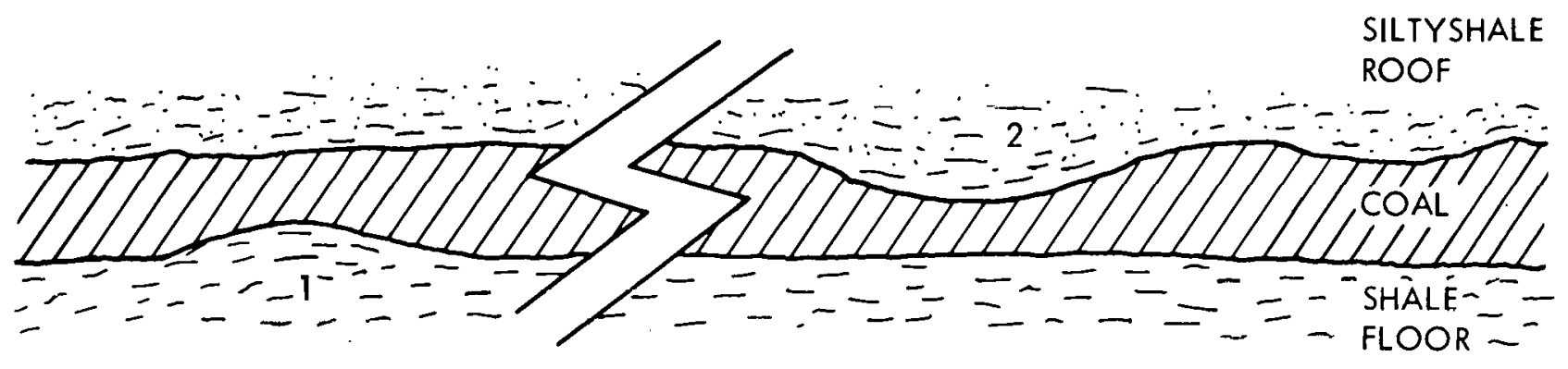

(1) FLOOR ROLL

(2) ROOF ROLL

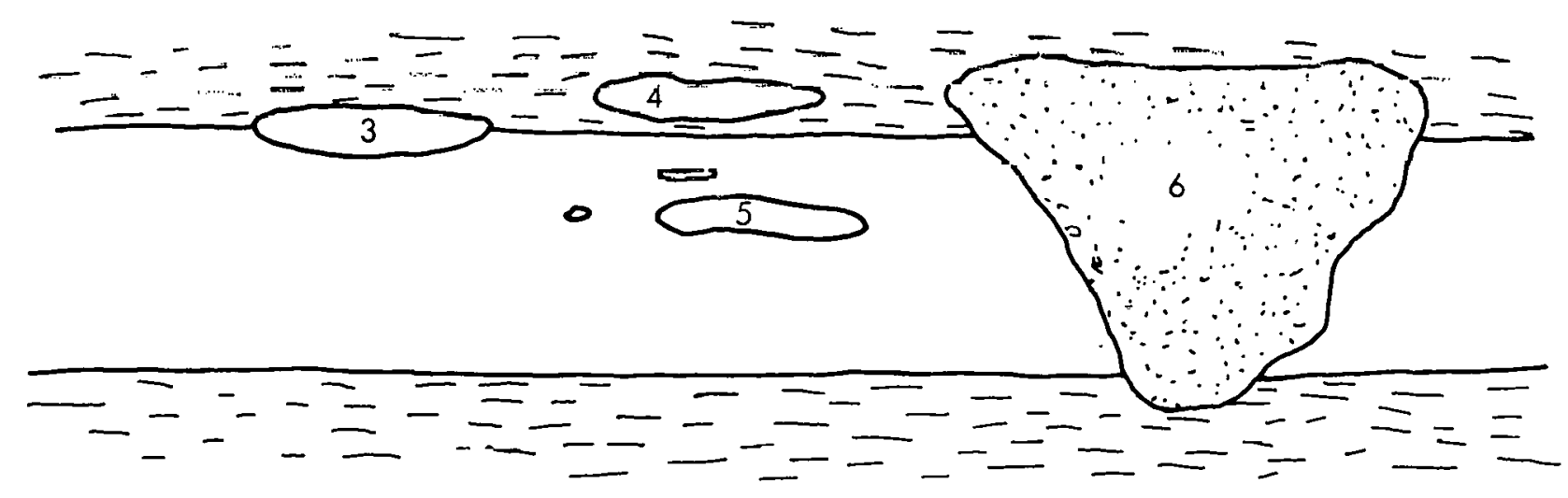

(3) CONCRETION PROTRUDING FROM ROOF

(4) CONCRETION HIDDEN IN ROOF - CAN FALL OUT UNEXPECTEDLY

(5) CONCRETIONS IN COAL - DIFFICULT CUTTING CONDITION

(6) SANDSTONE CHANNEL WASH OUT

(7) CLAY VEIN

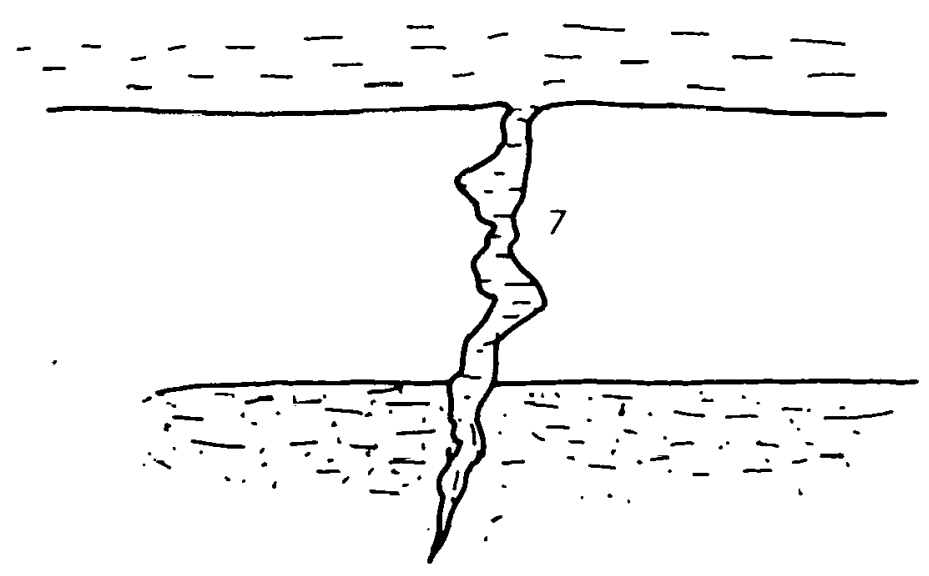

Figure 2-2. Depositional Features Associated With Coal Deposits 
contacts, and scour and fill interfaces. The tendency of sedimentary rocks to exhibit a pronounced fabric introduces a problem of dissimilar material behavior characterization. When considering a mine entry, this situation of anisotropy or nonuniformity causes the roof to behave as a series of beams or plates. The plate boundaries are defined by bedding planes or stratigraphic contacts.

Secondary sedimentary structures are caused by physical or chemical accretionary processes, occurring at the time of sedimentation or shortly thereafter. Concretions are an example of such a process. Concretions are hemispherical nodules of claystone (shale), pyrite, siderite, or calcite that range in size from microscopic to several feet in diameter. They are the result of the chemical precipitation that commonly form around a nucleus such as a fossil. Concretions include the host rock, but tend to be denser. Differential compaction around the nodules caused the formation of slick surfaces that have little adhesion to the surrounding rock, thereby allowing concretions to fall out of the roof easily. In some shale roofs, concretion populations are quite dense and result in severe roof problems. Concretions within the coal seam play havoc with cutting machines and must occasionally be blasted out. Pyritic concretions (sulfur balls) and iron carbonates (coal balls), in addition to being a source of pollution during combustion, are extremely hard and may create a safety hazard by sparking if hit by the'mining machinery.

e. Mechanical Discontinuities. Coal strata rarely act as homogeneous isotropic masses, due partly to the previously mentioned material variations and the presence of mechanical fractures. In fact, it is likely that the majority of roof failures occur along pre-mining discontinuities. Structural discontinujties are the result of stress applications occurring either during the rock formation phase (syngenetic), or after set-down (post-diagenetic). Stresses may have originated during the diagenetic process or from tectonic sources. The distinction between classes is morphologically difficult to ascertain, but the causative processes provide valuable insights. Mechanical discontinuities include slickensides, cleats, joints, faults, and fractures zones.

Slickensides. Slickensides are surfaces of little cohesion distinguished by a shiny face and caused by differential movement across the surface. Because slickensides are associated with a number of phenomena, they are not usually categorized in a class by themselves. In fact, slickensides imply only a surface with little cohesion.

Coal measure sediments exhibit a wide range of compactional properties. Shales may reduce in volume from 15 to $50 \%$, whereas sandstones will compact only 10 to $15 \%$ of their original volume. The difference in compaction causes relative movement across a shale-sandstone interface and creates slickensides. Slickensides are also associated with kettles (petrified tree stumps), concretions and clay veins, and occur across any other feature which has different consolidation rates. Slickensides are found along the failure surfaces of slump features. Minor "slicks" may also be found in shale clasts nr sal.ts that are rich in clay minerals or sandstones. More significantly, slickensides can generally be associated with poor roof. Determination in each case of the cause of slickensides will help to determine the extent of 
bad roof, and provide hints concerning the type of corrective support. system that will be most effective.

Cleats. Cleats are high-angle, orthogonal joint systems that pervade most coal beds. The cleats are perpendicular to the coal bedding plane and represent surfaces of preferred failure. The better developed set is called the face cleat, while the less prominent set is referred to as the butt cleat. Cleat formation has been variously attributed to dehydration, devolatilization, and/or tectonic stress application. Although usually limited in extent to the coal or (occasionally) the immediate roof and floor, cleats tend to parallel regional tectonic features. Local structures such as faults and folds can cause deviations in the orientation of the cleat surface. Anomalous changes in cleat attitude may be seen as a precursor to the nearby presence of tectonic structures. Although the lateral extent of any given cleat plané is limited, the homogeneous interfacing and connection with regional joint systems provides pathways for methane and groundwater. As a result, pronounced differences in methane emissinns can be easily realized by varying the orientation of the face of the coal bed plane with respect to face cleat attitude.

Cleat spacings vary from millimeters to meters and by their nature exhibit no tensile and little shear strength across the cleat plane. Proper orientation of the mine plan to the cleat can reduce cutting energies by as much as $50 \%$, resulting also in decreased respirable dust generation. However, when entries are parallel to face cleats, rib sloughing can be a cause of concern.

Joints. Joints are planar fractures that are caused by natural forces, across which negligible movement has occurred. Joint planes may be restricted to single beds nr transect entire rock soquonoco. Their occurrence, frequency and orientation reflects tectonic influence, but they can also be caused by the removal of a closely adjacent lower seam. Therefore, a knowledge of the local structural. geology can usually provide information on joint occurrence. Joints rarely occur alone. Spacing frequencies range from inches to hundreds of feet. Joints provide little strength in tension and shear because joint strength depends on (1) cohesion, (2) normal stresses across the plane and (3) the rock's coefficient of friction.

The rranslithologic extent of some joints causes them to be excellent conduits for groundwater and gas migration, particularly across impermeable strata. "Open" joints can prove to be troublesome when mining takes place under bodies of surface water or mine pools. A higher density of joint occurrence in the roof (near fault zones) can also cause problems.

Faults. Faulting is a deformational manifestation of tectonic stresses. Faulting in central Appalachia is found to be of two basic types: postdepositional and penecontemporaneous.

Postdepositional faulting can extend hundreds of miles and disrupt strata with thousands of feet of offset. The shear zone (gauge zone) is often filled with crushed rock (breccia) which can act as an excellent hydraulic conduit, or if weathered to clay, can act as an impermeable barrier. High water and methane pressures have been occasionally associated with fault 
zones, causing in-rushes or gas bursts. The density of joints also tends to increase in the vicinity of a fault, thereby causing severe roof problems. An unsuspected fault can obviously create a disruption in the mining cycle. Minor faults with displacements of several feet will require the construction of ramps up or down to the continuing seam. This requires exposing fractured roof or floor of dubious structural integrity.

Penecontemporaneous faulting does not cause the failure problems that postdepositional faulting can, although both can adversely affect the coal geometry. Tectonic activity occurring simultaneously with peat formation will cause severe changes in the depositional-erosional scheme. For example, resulting fault scarps can act as dams to lateral stream migration on the down-faulted side, thereby causing severe erosion immediately adjacent to the downthrown side of the fault. "These areas will most likely have a high incidence of sandstone channels and should be approached with caution. The upthrown side creates structural highs and allows the development of soil structures (roots, burrows, dessication cracks, etc.). These areas usually exhibit poor roof characteristics.

Fracturing of the roof, coal, and floor strata can also occur as a result of the high-stress modifications caused by the mining activity. Recently, certain geomorphic features identifiable by aerial photo and remote-sensing techniques have been correlated to poor roof conditions (Rickenberger, 1979). Features such as lineaments, stream valleys, and confluences may be either structurally controlled (joints and faults) or may affect the roof by overburden stress relief.

\section{BASELINE MINE}

The preceding text briefly described the various types of geologic phenomena affecting mining. In this final part of Section II, the phenomena will be grouped together to form a matrix of geologic parameters with varying degrees of severity. A set of values for each of these parameters will then be used to define the baseline mine. The chief advantage of this method is that the engineer will have the flexibility to structure the configuration of the model to match. that of the system concept. Such a technique will allow identification of system 1 imitations with a minimum of effort by the designer at the crucial conceptualization stages. If significant reserves are still considered addressable within the system 1 imitations, then the concept should be considered viable and its development continued.

The above approach will not only allow the determination of system limits, but it may also provide some insight as to system flexibility. No matter how detailed the premining geologic investigation, it must be understood that unexpected conditions will occur. They may be either advantageous, such as increased seam thickness, or disadvantageous, such as the presence of poor roof, faults, pinchouts, etc. Many of these conditions cannot be predicted at this stage of development.

Table 2-3 lists the parameters which should be considered when evaluating a new mining system. The first five items will have values assigned by the system designers. The remaining geologic parameters will be presented in the baseline mine matrix to illustrate the severity of the mining 
Table 2-3. Parameters of Baseline Mine

\section{Nominal Constants}

Seam Thickness
Depth
Depth Variations
Subsidence
Access

Seam Thickness

Depth

Depth Variations

Access

\author{
Matrix Variables
}

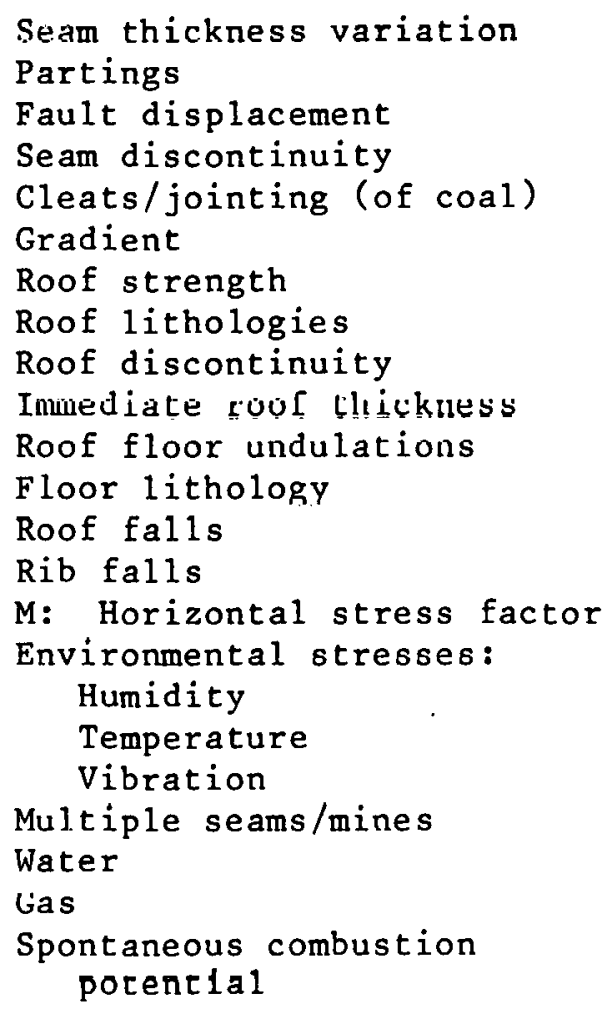

Seam thickness variation

Partings

Fault displacement

Seam discontinuity

cleats/jointing (of coal)

Gradient

Roof strength

Roof lithologies

Roof discontinuity

Imwediate rool llickness

Roof floor undulations

Floor lithology

Roof falls

Rib falls

M: Horizontal stress factor

Environmental stresses:

Humidity

Temperature

Vibration

Multiple seams/mines

Water

Gas

Spontaneous combustion potencial

conditions under which the system must operate. The values of the parameters positioned in the left column of the matrix are the initial conditions and are the least stringent. The matrix is structured such that the values of the parameters depicting the mining conditions degrade or represent less favorable mining situations as the columns progress to the right. Consequently, an advanced mining system must have the capability of selectively advancing to the right of the matrix. Even though it would be unusual for all of the worst-case mining conditions to occur on one property, the system must have the adaptability to deal with the worst-case conditions, as they will undoubtedly be encountered at some location in the resource. 


\section{SECTION III \\ CHARACTERIZATION OF EASTERN KENTUCKY TARGET RESOURCE}

\section{A. INTRODUCTION}

Section III presents a case study of the target resource selected by the Advanced Coal Extraction Systems Definition Project, eastern Kentucky. A target or sample region was chosen so that the requirements, conceptualization, and design of advanced coal extraction systems could be more easily focused. Consequent1y, the intent of this case study is to describe, to quantify, and to characterize the coal resources of the sample location of eastern Kentucky.

The target resource has been analyzed using three distinct approaches to characterization. The first approach is the traditional approach of geologic investigation. This portion of the report describes the physiography, climate, structure, sedimentation, stratigraphy and resource estimate of the sample locality. The next approach is the application of the baseline mine concept developed in the previous section. The final set of analyses characterize the resource in terms of slopes, dips, outcrop accessibility, interburden and overburden thickness. It is planned to describe future target resources in the same manner.

\section{B. TRADITIONAL GEOLOGIC INVESTIGATION}

\section{Physiography}

The eastern Kentucky coal region lies within the Appalachian Plateau province and may be subdivided into three distinct areas, as shown in Figure 3-1. A description of these areas is provided as follows:

(a) The Cumberland Plateau is a northerly trending belt, from 15- to 45-miles wide, located in the southwestern portion of the coal field. The western boundary is formed by the Pottsville escarpment, an erosional feature created from lower Pennsylvanian sandstones and Mississippian limestone. The Pottsville escarpment is most distinct at its southern extreme, where it exhibits a 700-foot relief, but it diminishes to the north and is frequently absent in this area. A low, broad relief characterizes the Cumberland Plateau, and it is irregularly dissected by steep and narrow stream valleys.

(b) The Kanawah Plateau covers the majority of the Eastern Kentucky coal field. The relief increases from 300 to 400 feet in the north to as much as 2500 feet in the southeast, where it borders the Cumberland Mountain section. The topography ranges from hilly to mountainous, consisting of narrow, crooked stream valleys with only the major streams expressing narrow to moderately-developed flood plains. 


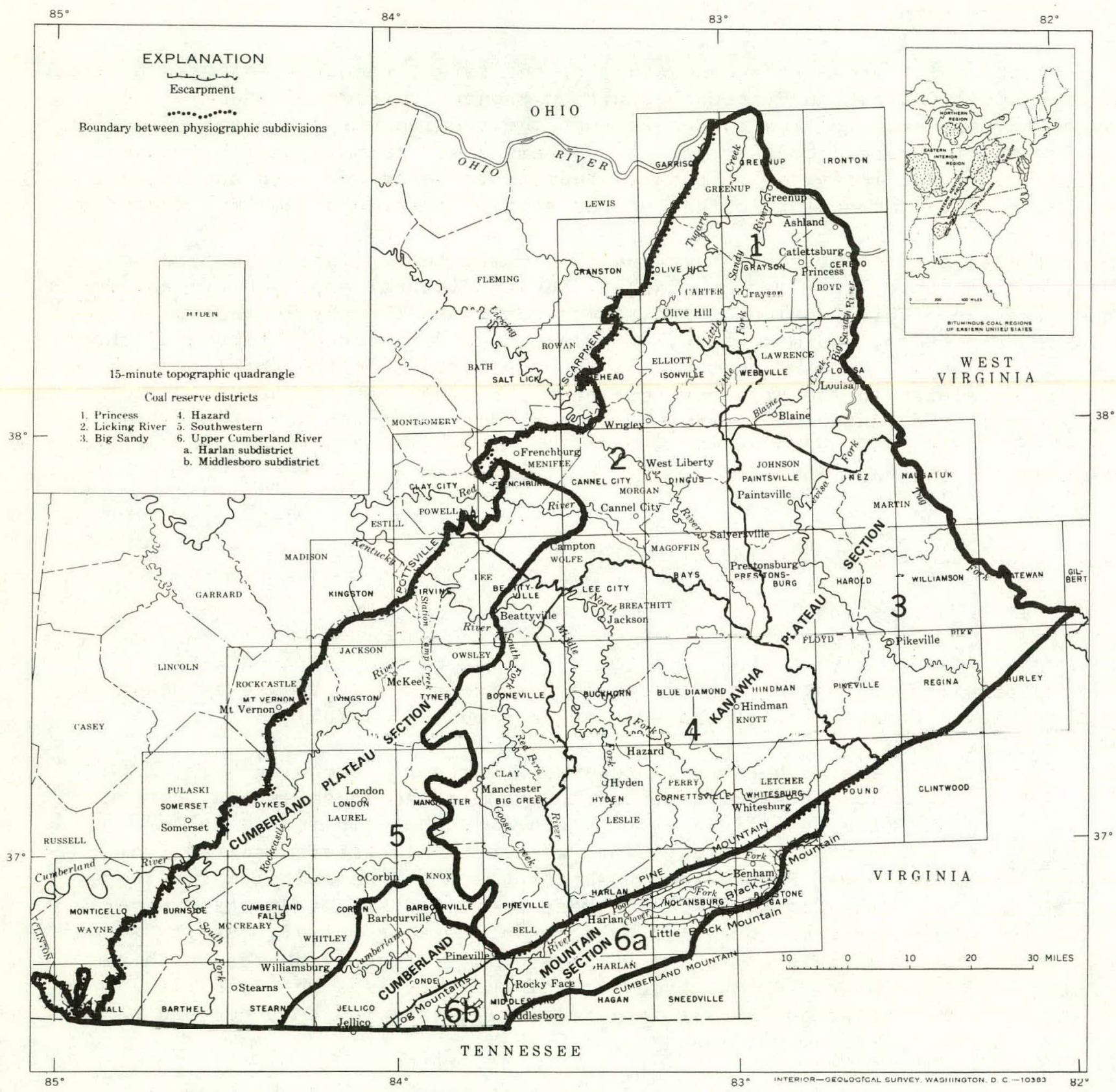

Source: Bulletin 1120, USGS (1963).

Figure 3-1. Index Map of the Eastern Kentucky Coal Field Showing Physiographic Subdivisions, Quadrangles, and Major Geographic Features 
Ridge crests slope from moderate to steep, though locally they may retain the flat topography of the plateau (peneplain surface).

(c) The Cumberland Mountain section was strongly influenced by the Pine Mountain thrust fault, and locally forms steep ridges with altitudes in excess of 4000 feet and reliefs on the order of 2500 feet.

\section{Climate and Drainage}

Kentucky is subjected to a temperate climate with temperature extremes ranging from $-10^{\circ} \mathrm{F}$ to $100^{\circ} \mathrm{F}$. Annual rainfall averages 42 inches, and is relatively consistent throughout the year. Precipitation per given storm may reach a maximum of 10 to 12 inches, although the average monthly rainfall is 3 to 4 inches. Seasonal variation of surface waters is considerable. Although the mean daily flow of surface water is significant, minimum daily flow is extremely small during the nonrunoff months and is insufficient to support coal preparation plant facilities. This situation is illustrated in Table 3-1. Year-round water reserves are limited to reservoir storage along the Ohio River. Groundwater yields are generally insufficient for large users, although they can adequately supply small communities. Average well yield is on the order of 10 gallons/minute, although higher flow rates occur at jointing or fracture intersections and concentrations.

\section{Geologic Structure}

The geologic structure exhibited in this area is relatively simple and consists of four major regions; the Allegheny synclinorium, the Irvine-Paint Creek uplift, the Eastern Kentucky syncline, and the Cumberland Mountain overthrust block. These regions are displayed on the structure-contour map of Figure 3-2.

The Allegheny (Pittsburgh-Huntington) synclinorium, trending northeast-southwest, extends into Kentucky from West Virginia, is gently plunging ( 1 to $2^{\circ}$ ), and contains the youngest (Conemaugh) coal-bearing formation. Forming the southern border of the Allegheny synclinorium, the Irvine-Paint Creek uplift is an east-west trending zone of folds, paired with normal faults that are downthrown to the south. Both fold amplitude and fault throw decrease to the west. The eastern Kentucky synclinorium forms the southern border of the Irvine-Paint creek uplift, and represents a broad, gentle downwarp, disappearing to the southwest. The Cumberland Mountain overthrust block is bordered by the Pine Mountain, Russell Fork, Hunter Valley, St. Paul and Jacksboro faults, and contains the Middlesboro synclinorium. The Russell Fork and Jacksboro faults are vertical and strike slip, while the remaining structures are low-angle thrust faults. The principal structural effect is to elevate and expose the deeper Lee formation along the Irvine-Paint Creek uplift and Cumberland Mountain. Locally, along the Rocky Face and Pine Mountain faults (as well as along some faults within the Irvine-Paint Creek uplift), tectonic activity has disturbed the coal to such an extent as to make it presently unprofitable to mine. Coal near the 
Table 3-1. Surface Water Discharge at Selected Eastern Kentucky Stations

\begin{tabular}{|c|c|c|c|c|c|c|}
\hline \multirow{2}{*}{ Gauging Station } & \multirow{2}{*}{$\begin{array}{c}\text { Drainage } \\
\text { Area, sq. mi. }\end{array}$} & \multirow{2}{*}{$\begin{array}{l}\text { Mean Flow } \\
\text { Oct. 1951- } \\
\text { Sept. 1952, } \\
\text { cfs }\end{array}$} & \multirow{2}{*}{$\begin{array}{l}\text { Average } \\
\text { Flow, cfs }\end{array}$} & \multicolumn{3}{|c|}{$\begin{array}{c}\text { Record Minimum Daily } \\
\text { Flow } \\
\end{array}$} \\
\hline & & & & & $\begin{array}{l}\text { Amount, } \\
\text { cfs }\end{array}$ & Date \\
\hline Levisa Fork, Fish Trap, Ky & 386 & 566 & $42 \overline{7}$ & & 0.1 & $11 / 9 / 39$ \\
\hline Levisa Fork, Faintsville & 2,143 & 3,183 & 2,302 & & 8.4 & $7 / 23-25 / 30$ \\
\hline Tug Fork, near Kermia, W. Va & 1,185 & 1,703 & 1,309 & & 23.0 & $9 / 14 / 39$ \\
\hline Little Sandy River, near Grayson, Ky. & 398 & 700 & 500 & & 2.0 & $10 / 26 / 39$ \\
\hline Tygarts Creek, Greenup & 241 & 374 & 316 & no & flow & $8 / 24 / 52$ \\
\hline Licking River, Salyersville & 140 & 253 & 164 & no & flow & ------ \\
\hline Licking River, Farmer & 826 & 1,457 & 1,054 & & 0.7 & $10 / 14 / 30$ \\
\hline North Fork Kentucky River, Hazard & 463 & 707 & 503 & & 1.0 & $1 / 9 / 41$ \\
\hline North Fork Kentucky, Jackson & 1,105 & 1,934 & 1,257 & no & flow & $10 / 16 / 30$ \\
\hline Middle Fork Kentucky River, Tallega & 530 & 963 & $65+$ & & 0.2 & $9 / 17 / 49$ \\
\hline South Fork Kentucky River, Booneville & 720 & 1,478 & 1,002 & & 0.1 & $10 / 1-7 / 30$ \\
\hline Kentucky River, Lock 14, Heidelberg & 2,648 & 4,934 & 3,513 & & $4 \cdot 0$ & $10 / 20 / 30$ \\
\hline Poor Fork, Cumberland & 82.1 & 169 & 141 & & 2.1 & $10 / 8-9 / 41$ \\
\hline Cumberland River, near Pineville & 822 & 1,728 & 1,306 & & 6.1 & $9 / 17 / 39$ \\
\hline Cumberland River, Cumberland Falls & 1,997 & 3,990 & 3,164 & & 8.5 & $9 / 19-20 / 32$ \\
\hline $\begin{array}{l}\text { South Fork of Cumberland River, } \\
\text { near Stearns }\end{array}$ & 942 & 1,917 & 1,810 & & 11.0 & $10 / 4 / 48$ \\
\hline
\end{tabular}

Average flow is given for entire record period to October 1952.

Source: U.S. Geologica1 Survey, Water Supply Paper. 


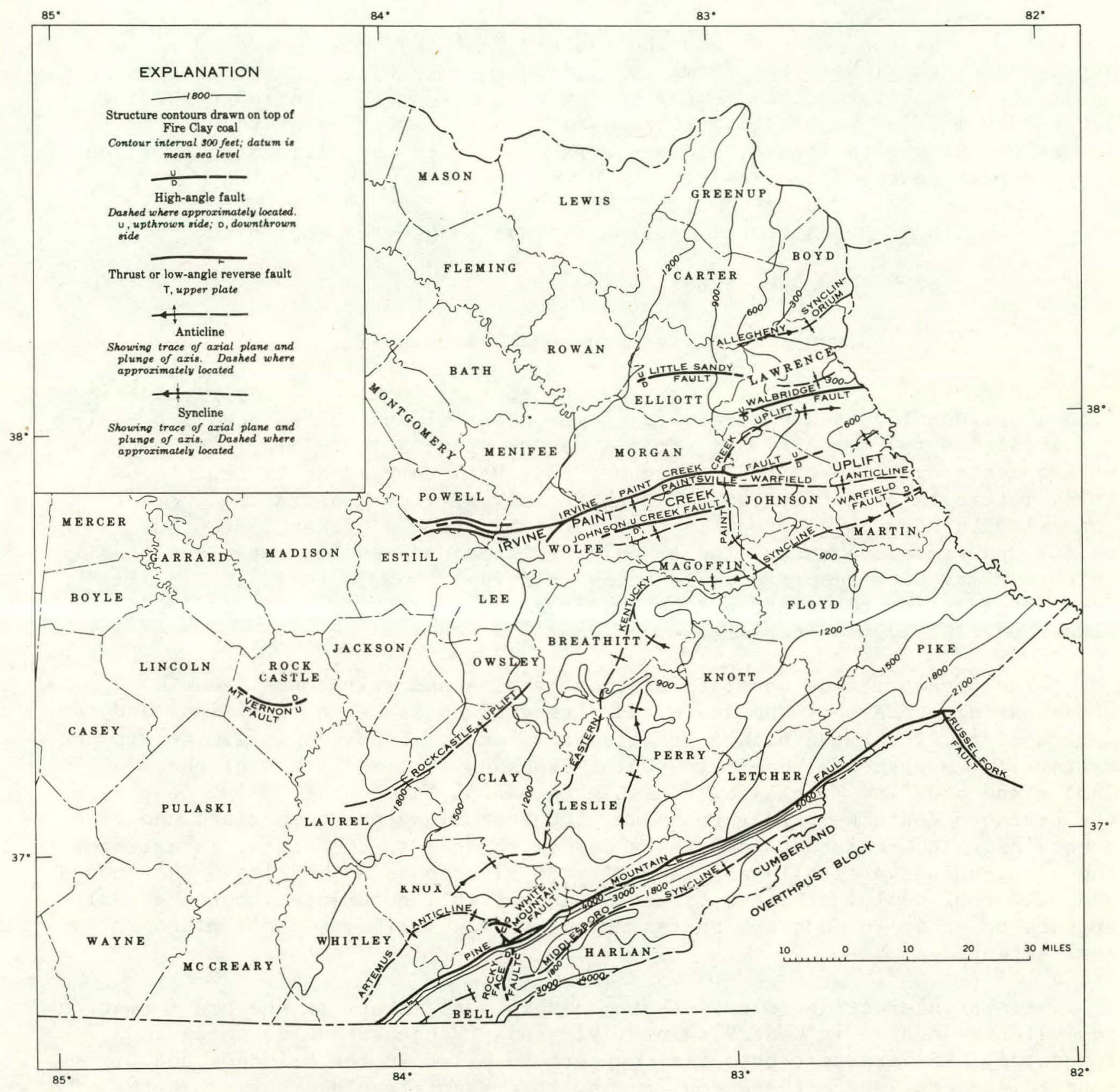

Source: Bulletin 1120, USGS (1963).

Figure 3-2. Structure-Contour Map of the Fire Clay Coal in Eastern Kentucky 
Pine Mountain overthrust exhibits locally steep dipping. In general, the dip of the synclinorium limbs rarely exceeds $1^{\circ}$ to $3^{\circ}$.

\section{Sedimentation and Stratigraphy}

The coal measures in the eastern Kentucky coal fields were deposited in the lower (Lee formation), middle (Breathitt formation), and upper (Conemaugh formation) Pennsylvanian systems during a period occurring 280 to 320 million years ago. The physical characteristics of these formations vary with locale, and are dependent on the specific site location with respect to the following:

(a) Depositional environment and syngenetic tectonism.

(b) Postdepositional tectonism.

(c) Recent and active erosional baselines.

In general, the depositional environments of Appalachia may be classified as either (1) back barrier, (2) lower delta plain, (3) upper delta plain - fluvial, or (4) transitional (from lower to upper delta plain). These environments are illustrated in Figure 3-3. Back-barrier coals tend to be thin, laterally discontinuous and high in sulfur. Lower-delta coals are generally thin and widespread in occurrence but have a higher content of sulfur and trace elements. The transitional and upper-delta coals are locally thick and may be widespread while being relatively low in sulfur. Depositional regions for the eastern Kentucky area have yet to be fully defined, either vertically or laterally.

The Lee formation consists of basal shales and siltstones (the coal-bearing members of the shale and fine-grained sandstone families) and the uppermost cliff-forming orthoquartzite sandstones. Exposure is limited to the Pottsville escarpment, the Irvine-Paint Creek uplift, and areas of the Cumberland and Pine Mountains. The Lee formation thickens from 100 feet along the northern Kentucky border to about 1500 feet along the Cumberland and Pine Mountains. The resistant sandstones become thinner to the north, interfingering and grading vertically and laterally to siltstones and shales. The amount and extent of coal in the Lee formation is not well documented, but the coal appears to occur in podshape bodies which are discontinuous and limited in a real extent.

It is interesting to note that mineable coal exists in the Lee formation equivalents located in West Virginia, Virginia (Pochahantas sequence) and Tennessee. The greatest potential appears to exist in the Princess and Big Sandy districts, where these coal zones, if present, would occur at depths of approximately 600 to 900 feet. The Breathitt formation contains mainly shales, siltstones, arkosic sandstones, and some carbonates. The Breathitt has the largest exposure area in eastern Kentucky and is complete only in parts of Boyd, Carter and Lawrence countries (northeastern segment). The Breathitt also thickens to the southeast, varying from 475 feet under the Conemaugh formation to 1300 feet near Pine Mountains. 


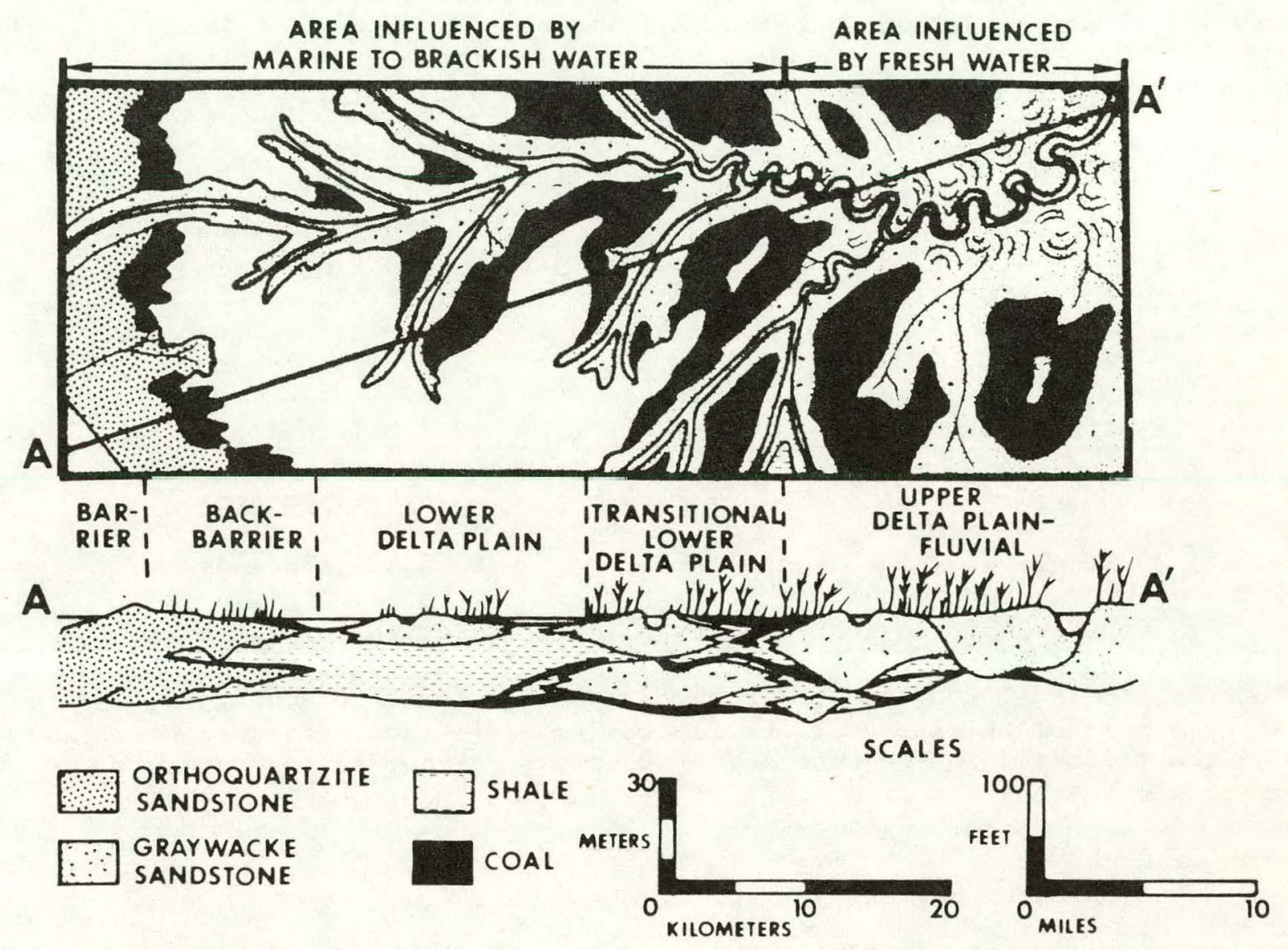

Source: Horne, et al (1978).

Figure 3-3. Depositional Model for the Peat-Forming (Coal) Environments in Coastal Regions 
According to a 1955 estimate, $97 \%$ of the coal reserves of eastern Kentucky lie within the Breathitt formation, and $73 \%$ of these are found to exist in ten counties; Pike, Harlan, Knott, Perry, Leslie, Letcher, Breathitt, Floyd, Martin, and Magoffin. This situation is illustrated in Figure 3-4. No single county of the remaining 18 counties contains more than 1 billion tons of coal.

The majority of estimated original coal reserves are found in seven seams and these are tabulated below as follows:

$\begin{array}{ll}\text { Upper Elkhorn } 3 \text { 3 } & 4.9 \text { billion tons } \\ \text { Fire Clay } & 4.2 \text { billion tons } \\ \text { Upper Elkhorn 非 } & 2.7 \text { billion tons } \\ \text { Fire C1ay Rider } & 2.7 \text { billion tons } \\ \text { Amburgy } & 2.3 \text { billion tons } \\ \text { Upper E1khorn 非 } & 2.2 \text { billion tons } \\ \text { Hazard 非7 } & 1.8 \text { billion tons } \\ \text { TOTAL } & 20.8 \text { billion tons }\end{array}$

The Conemaugh formation consists principally of shales, with some siltstones and sandstones and minor lenses of limestone and chert. The areal extent is limited to portions of Boyd, Carter and Lawrence countries, and it reaches a maximum thickness of 500 feet. Two coal seams, Princess No. 9 and No. 10, are located in the Conemaugh formation; neither of them are commercially mined.

\section{Resource Estimate}

A11 of eastern Kentucky's coals belong to the bituminous class, and most are identified as belonging to the high-volatile "A" rank. The remaining coals are classified as being of the "B" rank. The magnitude of the total coal resources in the region, including the hypothetical, is 54.9 billion tons. This estimate excludes coal resources that exist in the western half of the state. The resource is inventoried and audited into a family of about sixty coal beds, none of which appear consistently across the sample territory. These discontinuous beds are mainly mapped and correlated by their respective positions in the Pennsylvanian stratigraphy.

Only part of the total eastern Kentucky coal resource is potentially mineable and an even smaller portion has contemporary economic significance. A categorization of the coal resources in this region is provided in Table 3-2. It should be noted that resources are defined as those deposits of coal in such form that extraction is currently and/or potentially feasible. 


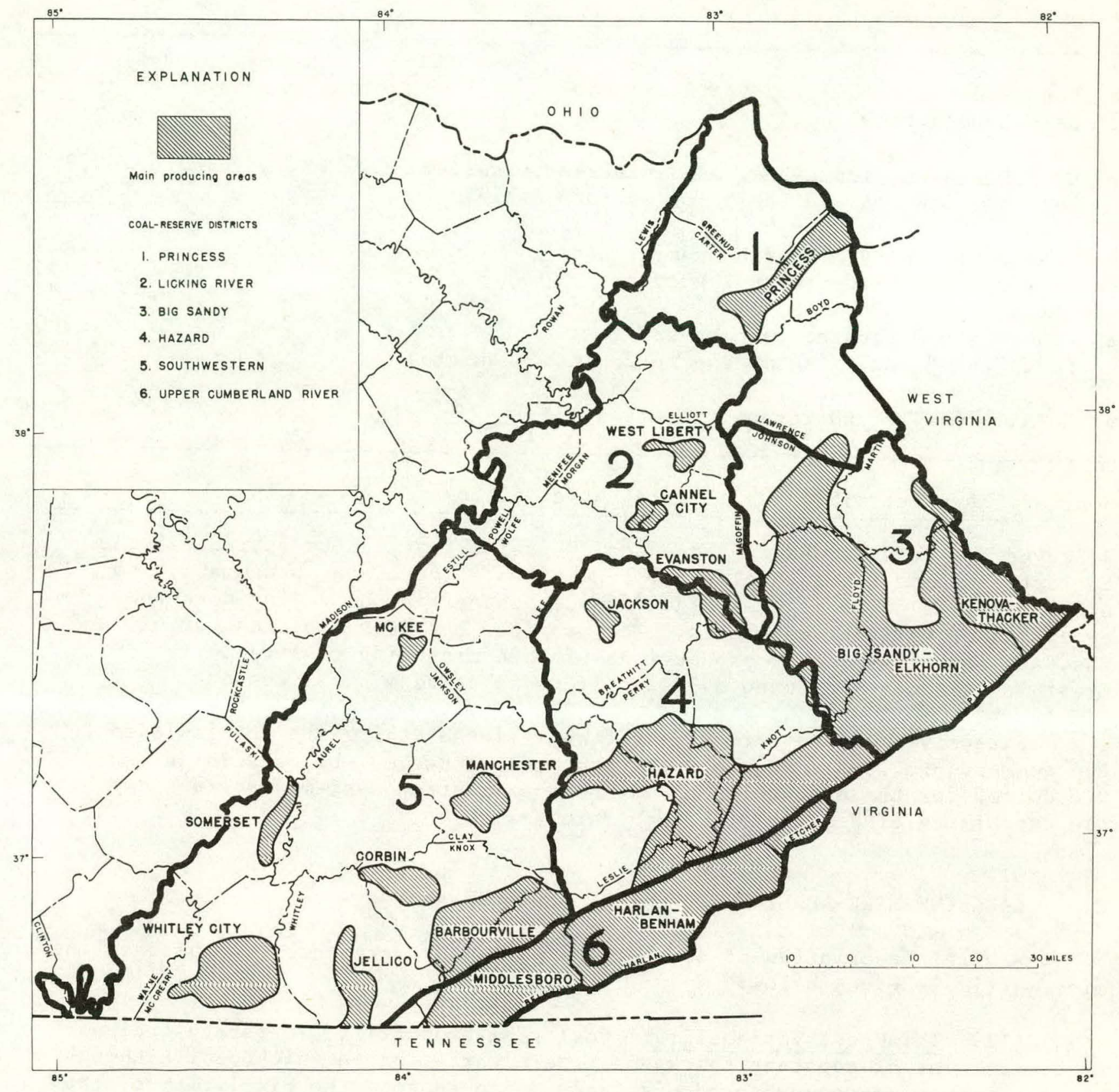

Source: Bulletin 1120, USGS (1963).

Figure 3-4. Coal Reserve Districts and Main Producing Areas in Eastern Kentucky 
Table 3-2. Bituminous Coal Resources of Eastern Kentucky, tons $\times 10^{6}$

- Resources attributed to the province:

54,900

Less hypothetical quanta:

24.000

- Coal measured, indicated, and inferred by survey:

30,900

Less shallow coal suitable for surface mining:

$\underline{-4,400}$

- Coal potentia11y mineable underground:

26,500

Less coal in "inferred category":

$-5,200$

- Mineable underground resources:

21,300

Less "thin" coals (seams 14- to 28-inches thick):

$\underline{-9,100}$

- TOTAL mineable underground reserves

12,200

Sources: Averitt (1975) and Huddle, et al (1963).

Reserves are categorized as those coal deposits that can be extracted under current economic and technological conditions. There are, presumably, no other minerals of commercial significance present in the region with the exception of building materials. The province has been explored for oil and gas, and some very modest productions of both are being realized. The Breathitt sediments show no evidence of radioactive mineral content.

Extensive coal resources less than 14-inches thick are not included in the summary provided in Table 3-2. They must, however, be considered a "resource" for the evaluation of advanced extraction systems, as they may have the capability of dealing with such thin seams.

\section{BASELINE MINE APPLIED TO EASTERN KENTUCKY}

A brief description of some of the parameters presented in the baseline mine matrix is given below:

(1) Thickness Variability: Coal seam boundaries are rarely coplanar or of constant thickness. Zero variation in thickness, although seldom encountered, is included to enhance the simplicity of the mine model. A variation of 12 inches is probably the most common occurrence over a short span, and a thickness deviation of 24 inches can be expected over large areas. A variation in thickness of 24 inches in a 48 inch seam should be interpreted as a seam thickness ranging from 24 to 72 inches.

(2) Partings: Numerical values in the matrix refer to parting thickness. Partings may be vertically located anywhere within the seam, and multiple partings are not uncommon. Partings may seriously affect cutting efficiency or roof support if top coal is left behind, and their hardness may cause guidance problems in auger-type miners. Some parting lithologies become extremely 
slippery when wet and result in difficult floor conditions. The presence of partings will also add to product preparation cost.

(3) Faults: Numerical values in the matrix refer to the vertical seam offset resulting from a fault. In many areas, 5- and 10-foot offsets are not uncommon. An offset of 20 feet is the maximum seam displacement resolvable by present geophysical techniques. Faults create poor roof conditions and affect system flexibility. Faults often act as dams, retaining water or methane, and they can also serve as a conduit for surface waters.

(4) Seam Continuity: Coal seams are often dissected by pinchouts, washouts, sandstone channels, etc. The numbers listed in the baseline mine matrix refer to the width of the interruption. This parameter can seriously affect the mine plan. The vicinity near the discontinuity is often highly fractured, contributing to poor roof conditions. Because the detection of discontinuities is not always achieved, contingency plans should be developed in the event of surprise encounters.

(5) Cleats: A quantitative method of relating the frequency of cleat occurrence as a function of any other geologic parameter has not yet been developed. A dominant cleat set will have a significant influence on water seepage, gas migration, cutting efficiency and rib stability.

(6) Gradient: Overall mine gradients or slopes can influence water seepage and the handling of materials. At the higher gradients, stress distributions around entries may be altered, causing high shear stresses. Steeper gradients also influence ventilation patterns and will affect the choice of mining directions.

(7) Roof, Pillar strength: The terms noted in the matrix for this parameter are useful for general model construction. The values will provide descriptive input for system roof support needs, mine layouts and rib stability.

(8) Roof Lithologies: These terms are intended to highlight the fact that numerous roof-support systems will likely be necessary to accommodate the variety of roof lithologies. This will require mine plan flexibility.

(9) Roof Discontinuities: Although analytical techniques are available, the infinite variations possible make quantification of discontinuities cumbersome. Extensive discontinuity occurrences will affect roof and pillar stability. These situations may affect the mine layout and will probably require modifications to the roof-support systems as the frequency of discontinuities increases.

(1.0) Immediate Roof Thickness: These numerical values reflect the thicknesses of common roof falls and roof-bolt lengths. This parameter is related to roof strength and these values may be used as input to beam and plate formulae for roof designs. 
(11) Floor Lithology: The term "clay-wet" implies that the floor consistency is of a soft, plastic nature and is probably slippery. "Clay-dry" implies a stable floor unless it is wetted (e.g., by dust suppression sprays or hydraulic cutting systems). Rock floors may be any lithology of high strength. This floor-lithology parameter will limit component weights, cutting systems, and haulage systems. Furthermore, this factor can affect rib and roof stability as well as the mine layout.

(12) Roof and Rib Falls: These values represent typical fall sizes. The quantity of material involved in the falls may be as great as in the millions of pounds. The weight given is that of the material only and does not include impact momentum.

(13) Convergence: The squeezing or closure of the original mine opening may be the result of elastic or plastic flow, floor heave or roof sag. This is a critical factor to consider in roof-support (packing) systems and in tight mining systems with little clearance.

(14) M: $M$ is the proportionality constant used to determine horizontal stress. The vertical stress component $\left(S_{v}\right)$ is a function of the mine depth and is obtained by multiplying the mine depth in feet by 1.1 to obtain the value for $S_{v}$ in psi. The horizontal stress component $\left(\mathrm{S}_{\mathrm{H}}\right)$ is calculated by multiplying $\mathrm{S}_{\mathrm{v}}$ by the proportionally constant (M). A value of zero for $M$ is equivalent to uniaxial conditions, or near valley, shallow deposits. The standard theoretical value for biaxial conditions is $M=1 / 3$. When $M-1$, it represents the hydrostatic stress state such as is found in deeper mines.

(15) Environmental Stresses: These are unquantifiable stresses introduced by the mining process. They include humidity (clay expansion), temperature fluctuations, vibration, etc. Such stresses can affect roof, rib and floor stability.

(16) Multiple Mines: When considering the extraction of multiple coal seams, it may be necessary to consider the stress interactions between excavations. The mine layout will vary depending on the location, distance, seam thickness and sequencing of the respective seams. Old mine workings require accurate detection techniques, due to the threat of mine pools, or gob gas concentrations.

(17) Water: Water pressures may affect the stability of impermeable liners and of the floor/root/ribs in addition to the effectiveness of some support systems. The presence of water must be regarded a considerable negative factor.

(18) Gas: The presence of gas does not directly affect strata control, but the mine layout of gassy seams must be dictated by ventilation requirements.

(19) Spontaneous Combustion Potential: Although this factor is not as critical in the east as in the western coal fields, high potentials may affect overall mine layout, especially ventilation design. 
The data pertaining to the target resource is presented in Table 3-3. The table depicts the baseline mine matrix for eastern Kentucky.

\section{COAL RESOURCE ANALYSIS}

The coal resources of eastern Kentucky possess some characteristics that lend themselves to quantification and which may be useful to the operations planner and systems designer. Most of the analysis which follows draws heavily from Reference 6, Bulletin 1120, USGS (1963).

\section{Nature of Topographic Slopes}

The typical slope of the landform surfaces in eastern Kentucky was analyzed in order to describe resource assessibility. Analysis of a large number of 7.5-minute topographic quadrangle sheet maps led to the following observations:

(a) In sectors dominated by the typical nonresistant facies of the Breathitt formation (the shales, siltstones, some sands), the hill and ridge slopes tend to fall at or about 12 degrees.

(b) Where the more resistant Breathitt members outcrop, the slopes steepen, and tend to fall at or near 26 degrees.

Generally, the softer landform surfaces (lower relief and more mature landscapes) are situated in the northern part of the province, where the Ohio River begins to exert dominance over the topography.

\section{Dip of Coal Seams and Thickness}

The dip (angle of slope) of the coal resources located in eastern Kentucky was examined in some detail. Of the 220 quadrangle sheet maps that describe the province, 52 were analyzed, with particular emphas is given to those areas where significant deformation is known. The results of this analysis are provided in Table 3-4. It is obvious that the overwhelming majority of the coal resources covered in this analysis are essentially flat-lying. Accordingly, it was concluded that the ability to mine steeply-dipping seams need not be a requirement for the advanced extraction system utilized in this are:

\section{Relationship of Resource to Outcrop}

In the sample province of eastern Kentucky, where the relatively flat coal beds of the Breathitt formation outcrop extensively, an analysis was made of the relationship of topography and outcrop to the multiple coal seams in order to provide the designer with additional information regarding seam access. 
Table 3-3. Baseline Mine for Eastern Kentucky (Seam thickness, depth, depth variations, subsidence, and access to be chosen by designer)

Parameter:

Initial conditions - Degrade to Right

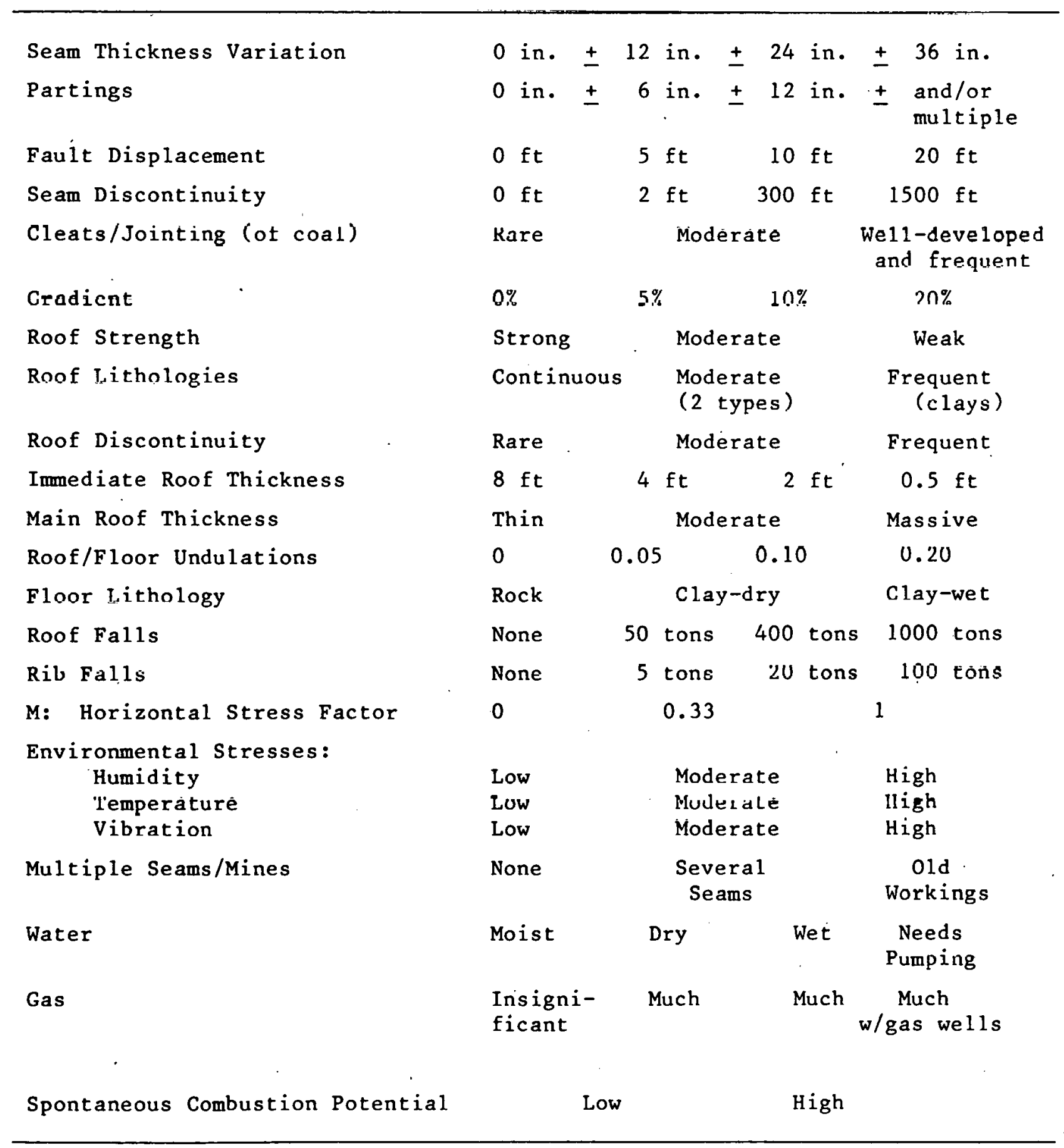


Table 3-4. Coal Seam Dip Relationship to Thickness in Eastern Kentucky, tons $x \cdot 10^{6}$

\begin{tabular}{ccccc} 
& \multicolumn{4}{c}{ DIP } \\
\cline { 2 - 4 } Seam Thickness, in. & $0^{\circ}-3^{\circ}$ & $3^{\circ}-10^{\circ}$ & $+11^{\circ}$ & TOTAL \\
$14-28$ & 9100 & 0 & 0 & 9100 \\
$28-42$ & 5257 & 33 & 0 & 5290 \\
$42-120$ & $\underline{3871}$ & $\underline{5}$ & $\underline{0}$ & $\underline{3876}$ \\
TOTAL & 18,228 & 38 & 0 & 18,266 \\
\hline
\end{tabular}

Mapped seams were measured by planimeter, and a typical thickness hypothesized from the literature. Contours were plotted inwards 200 feet from the outcrop, followed by 500 feet, and then 1000 feet. Thus, for each seam, the resources were categorized to establish the amount of coal available within the previously stated distance ranges from outcrop occurrence.

The present effort measured only two quadrangles: the Grayson in District 1 , and the Broadbottom in District 4 . The results are displayed in Table 3-5. From Table 3-5 it can be seen that about $60 \%$ of the coals in the Grayson Quadrangle lie within 200 feet of the outcrop, whereas only $20 \%$ of the resources in the Broadbottom Quadrangle are similarly situated. Examination of the landforms and their relationship to where each quadrangle lies in the drainage network reveals the principal reason for the observed differences in seam access: the Grayson Quadrangle, characterized by low, narrow ridges, is located near the floodplain of the Ohio River in relatively mature topography. In contrast, the Broadbottom Quadrangle, exhibiting higher relief and broader ridges, is situated in the headwaters of its drainage network, near the Allegheny uplift. Thus, these two quadrangles probably portray the extremes in the range of topography conditions which determine what fraction of the coals lie within a certain distance of the outcrop.

\section{Resources Below Drainage}

Buried coal bodies in eastern Kentucky have not been completely explored nor fully described in the public record. This is partly because the Breathitt formation, which hosts practically all. of eastern Kentucky's commercially significant coal resources, is almost entirely exposed to its basement by the drainage system. The Lee formation, immediately below the Breathitt formation in the Pennsylvanian stratigraphy, is also exposed, at least in portions of the province. However, due to the thin and discontinuous nature of the coal seams in the Lee formation, minimal commercial significance is attributed to it. In other words, there was no attempt to map buried resources. 
Table 3-5. Coal Resources Related to Outcrop, tons $\times 10^{6}$

Seam

Thickness, in.

Feet From Outcrop

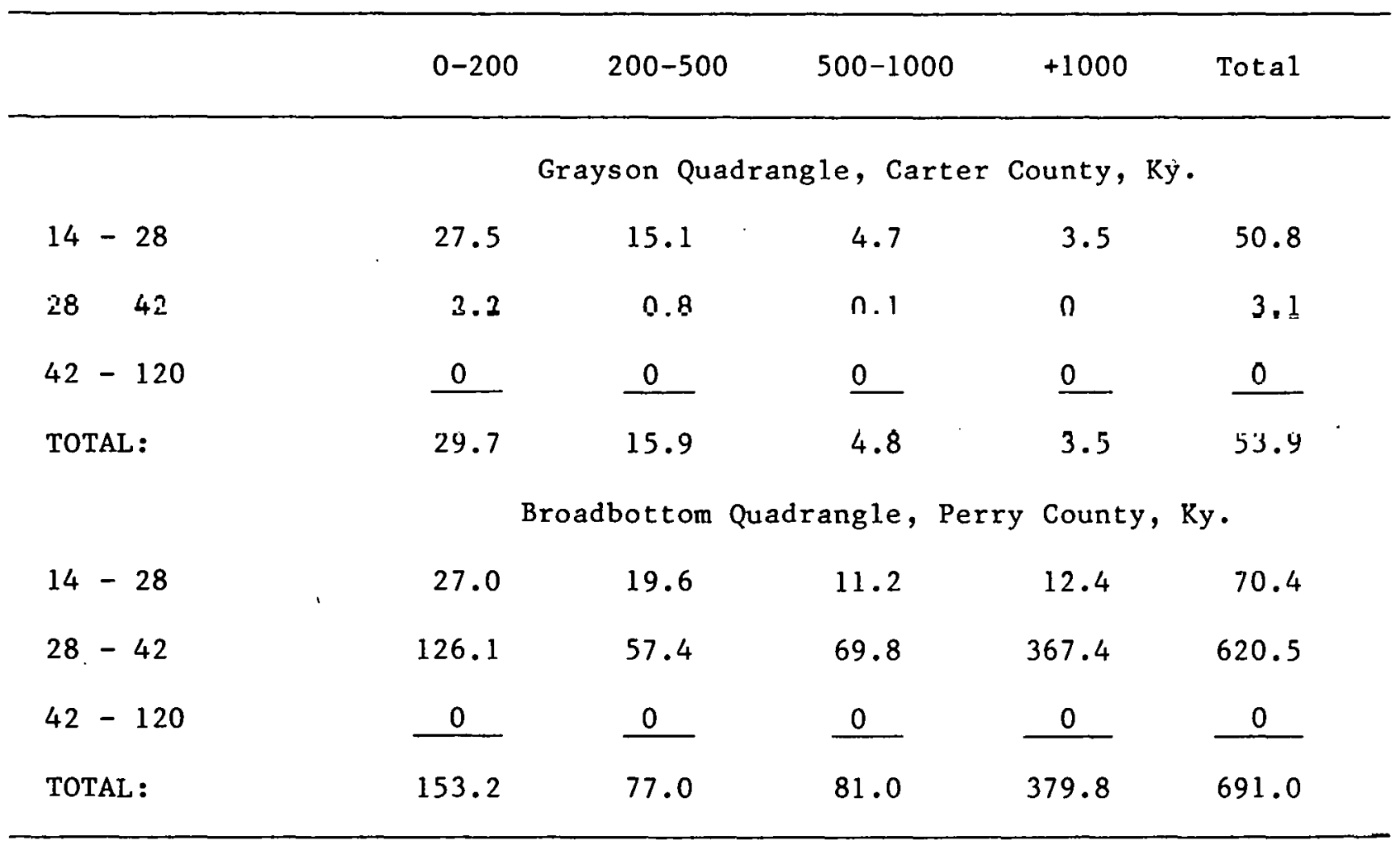

Note: Resources less than $14-i n$. thick are not included.

5. Relationship. of Resource to Interburden

To assist in the conceptualization and design of an advanced extraction system, the study has sought to identify, analyze and characterize the sedimentary rock interburdens that exist between coal members. Two avenues of inquiry were followed; (1) quantification of the interburden dimensions, and (2) characterization of the nature of the interburden materials. The first was completed and its conclusions are indicated in Figure 3-5. It was found that no meaningful generalization was possible regarding the composition of the interburden material.

The results presented in Figure 3-5 indicate that $64 \%$ of eastern Kentucky's coals lie in bodies separated from the next superimposed body by a sedimentary-rock thickness of over 60 feet. The balance is more narrowly separated, and in these situations the mining of one seam may impede or prevent access to neighboring seams. This has major consequences for the ultimate recovery of these resources. 


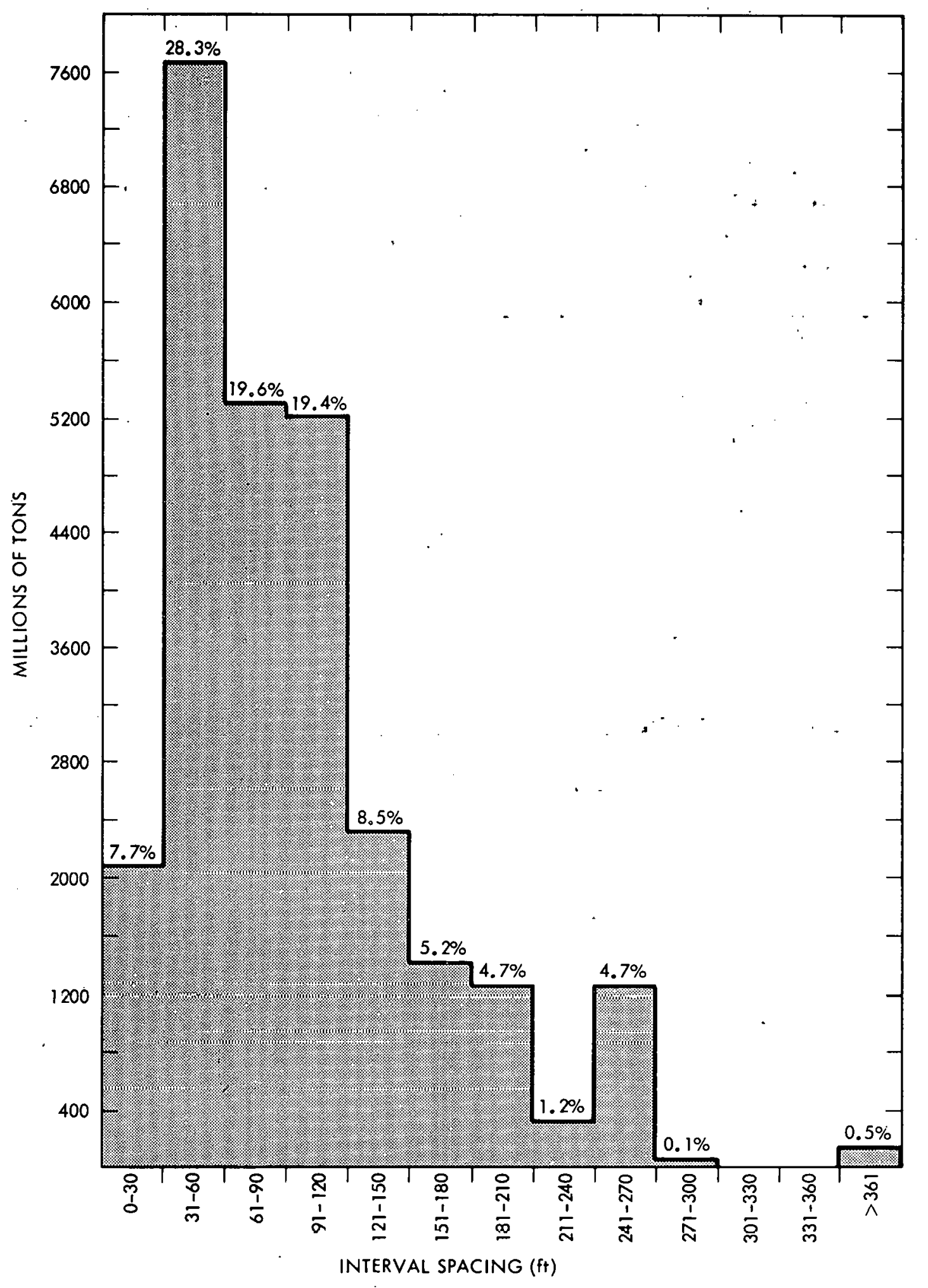

Figure 3-5. Percentage of Eastern Kentucky Coal Resources Which are Separated from Adjacent Coal Seams by a Specified Interburden. Distance 


\section{Overburden Thickness}

The mature rolling topography of the sample province, superimposed upon an irregularly spaced series of almost flat coal horizons, establishes overburden in a haphazard pattern. An analysis paralleling the interburden study indicated the variation in overburden thickness across the province, as presented in Table 3-6.

Table 3-6. Overburden Above Coal

Vertical Feet

\begin{tabular}{|c|c|c|c|c|}
\hline District ${ }^{a}$ & Minimum & Seam & Maximum & Seam ${ }^{b}$ \\
\hline 1 & 84 & $\$ 77$ & 453 & 非67 \\
\hline 2 & 10 & 104 & 320 & 96 \\
\hline 3 & 20 & 111 & 263 & 100 \\
\hline 4 & 101 & 91 & 433 & 96 \\
\hline 5 & 190 & 111 & 585 & 212 \\
\hline 6 & 398 & 135 & 443 & 104 \\
\hline
\end{tabular}

${ }^{a}$ Districts from USGS Bulletin 1120 (1963).

beam numbers from ÜSBM IĆ 8655 . 


\section{SECTION IV}

\section{CONCLUSIONS}

This report is intended to aid and guide the system designers in their task of designing an advanced coal extraction system applied to the central Appalachian coal region. This intent was met partially by presenting a traditional geologic overview and a series of analyses applied to the target province, eastern Kentucky. The remaining aspects were fulfilled with the presentation of the baseline working environment concept. As the geologic overview and analyses will serve as an introduction to the target site for the system designer, the baseline mine concept will be the designer's working tool for integrating the advanced system design with the proposed mine environment.

In any mine system design, a certain hierarchy of planning exists. In the initial stages, the investigation and design are broad. As the project matures, the vision becomes more focused and better defined. Paralleling this planning hierachy is the geologic investigation with its associated level of confidence. Total $(100 \%)$ confidence is only achieved when the coal is exploited and viewed by the human eye. It should be noted that at the regional level (i.e., central Appalachia), the confidence of the geologic information is an educated guess at best. This is suitably exemplified by an excerpt from the introduction of GSA Special Paper 148, "Carboniferous of the Southeastern United States," edited by Garrett Briggs:

"More recent studies in many areas of the southeastern United States reveal that individual layers are not necessarily continuous, even across very small areas, but that they frequently pinch out or grade laterally into other rock types within a short distance. It was found that lithologic similarities between rock sequences at one locality and those at another reflect similar depositional environments rather than contemporaneity. Comparisons of mineral composition, sedimentary structures, and lateral relations of rock bodies of the Carboniferous with those of modern coastal sediments have influenced many geologists to abandon the concept of frequent but synchronous, widespread sea-level fluctuations, and to invoke transient and time-transgressive shoreline processes such as prograding deltas or migrating barrier islands to explain the sedimentary relations. Accordingly, the "layer-cake" model upon which Carboniferous stratigraphic nomenclature was based has yielded in many instances, to the adoption of three-dimensional depositional models of deltas, barrier islands, alluvial plains, and other coastal or fluvial phenomena which more accurately demonstrate or predict the vertical and lateral disposition of sedimentary units. In contrast with the established time-stratigraphic framework and the "layer-cake" model upon which it is based, many of the new depositional models emphasize the time-transgressive nature of the sedimentary units and de-emphasize, if not refute, the existence and duration of erosional surfaces of regional extent, even the one which has for so long been recognized as separating the Carboniferous systems.

"It is obvious from the foregoing that knowledge of the Carboniferous is in a state of flux. Both the long-established and more recent concepts of Carboniferous depositional environments are the subjects of much 
debate and controversy. Another problem encountered in studying the Carboniferous of the southeastern United States is that the results of much of the work, present and past, is scattered throughout a variety of diverse publications and that the studies were confined to a single basin of deposition. Consequently, a student finds that it is difficult to gain a regional overview of carboniferous rocks or their depositional history."

Because of the current variability and degree of uncertainty regarding geologic phenomena, it is hoped that more work along the lines of Ferm and Horne, 1979, as well as Pedlow, 1977, will be encouraged and completed in the future. By pursuing geologic investigations on site-specific levels, the authors of this report believe that such contributions will enable others to develop more refined (i.e., higher degree of confidence) investigations on the broad regional level. This will aid the system designers by giving them a more realistic feel of the mine environment, which will hopefully lead to acceptable alternatives for advanced coal extraction systems.

It is hoped that the framework presented in this report will provide a basis, allowing the same type of analyses to be performed for other geographic regions. Following that, the mining requirements of regional systems could be examined for similarities and differences. Furthermore, it will be possible by the review of nationwide data to reveal the differences in regional mining conditions. 
REFERENCES

1. Goldsmith, M., and Lavin, M. L., Overall Requirements for an Advanced Underground Coal Extraction System, JPL Publication 80-39.

2. Averitt, P., "Coal Resources of the United States in 1974," Bulletin 1412, United States Bureau of Mines, 1975.

3. Briggs, G. (editor), "Carboniferous of the Southeastern United States," Special Paper 148, General Services Administration, 1974.

4. Ferm, J. C., and Horne, J. C., Carboniferous Depositional Environments in the Appalachian Region, Carolina Coal Group, Department of Geology, University of South Carolina, 1979.

5. Horne, J.C., et al, "Depositional Models in Coal Exploration and Mine Planning in Appalachian Region," Carboniferous Depositional Environments in the Appalachian Region, pp. 544-575, 1979.

6. Huddle, J. W., et al, "Coal Reserves of Eastern Kentucky," Bu1letin 1120, United States Geological Survey, 1963.

7. McCabe, K. W., and Pascoe, W., "Sandstone Channels: Their Influence on Roof Control in Coal Mines," Mine Safety and Health Administration, I.E. $\underline{1096}, 1978$.

8. Pedlow, G. W., A Peat Island Hypothesis for the Formation of Thick Coal, Ph.D. Dissertation, Dept. of Geology, University of Carolina, 1977.

9. Rinkenberger, R. K., "Imagery Analysis: Predicting Hazards," Coal Mining and Processing, pp. 48-50, February 1979.

10. U.S. Bureau of Mines, "Demonstrated Coal Reserve Base of the United States on January 1, 1976," Minera1 Industry Surveys, 1977.

11. U.S. Bureau of Mines, "Reserve Base of Bituminous Coal and Anthracite for Underground Mining in the Eastern United States," Information Circular No. 8655, October 1974.

12. U.S. Geologic Survey, Water Supply Papers. 